\title{
Názvosloví studií státního převratu: jeho použití v odborné literatuře, 1962-2014
}

\section{The Terminology of Coup d'état Studies: Its Use in Specialized Literature Between 1962 and 2014}

\author{
LUKÁŠ MARTINÁK ${ }^{1}$
}

\begin{abstract}
This short study provides a comparative analysis of Anglo-Saxon scientific literature (in the form of monographs, articles from reviewed periodicals, Internet sources) in which the phenomenon of coup d'etat is the primary subject of research interest. The main goals of this text are (1) to increase awareness of research into coup d'état as an essential phenomenon in the sphere of transitology among Czech political science students, and (2) to present solutions to the terminological problems relating to this political science discipline. To achieve these goals, the text presents a coherent terminological concept of coup d'etat based on a semantic analysis of the disparate literature of Anglo-Saxon provenance, in which research into coup d'état has reached an advanced level of knowledge
\end{abstract}

Keywords: Coup d'État, Military Coup, Civil Coup, Revolutionary Coup, Autogolpe

\section{1. Úvod}

Podobor politické vědy, známý odborné veřejnosti jako tranzitologie (popř. teorie přechodů), si i po čtvrt století stále hledá v badatelském zájmu české politologické obce své místo. Ačkoli se tranzitologie zaměřuje na studium široké škály politických jevi̊, jež lze souhrnně definovat jako neústavní částečné, nebo zevrubné změny politického režimu, česká odborná literatura se téměř bez výjimky doposud věnovala pouze jedné z jejích větví: přechodům $\mathrm{k}$ demokracii. Zatímco díla Vladimíry Dvořákové a Jiřího Kunce (1994) a Marka Ženíška (2006) jsou zaměřena výlučně na přechody k demokracii - analýzu dosavadní úrovně teoretické konceptualizace přechodů $\mathrm{k}$ demokracii a, v druhém prrípadě, taktéž předkládající empirické ukotvení rozborem vybraných př́padových studií -, v monografii Blanky Ř́chové (2000) je přechodům k demokracii věnována pouze

\footnotetext{
${ }^{1}$ Ministerstvo obrany České republiky, Tychonova 1, 16001 Praha - Dejvice, Česká Republika / Ministry of Defence, Czech Republic. E-mail: 1.martinak@seznam.cz
} 
dílčí část badatelského záměru a slouží tedy jako shrnutí různých přístupů ke studiu rozpadu nedemokratických režimů. ${ }^{2}$

Původním impulsem pro vznik a rozvoj tranzitologie coby samostatné politologické subdisciplíny přitom bylo dominové hroucení politických režimů mladých států, jejichž vznik byl výsledkem třetí vlny dekolonizace v padesátých a šedesátých letech minulého století. Nikoli tedy pád autoritářských režimů, nýbrž jejich vznik na troskách veskrze nekonsolidovaných demokracií. Teorie přechodů tak vzniká jako odpověd' na neschopnost doposud dominantní teorie modernizace vysvětlit náhlé konce režimů materiálně i politicky podporovaných rozvinutými zeměmi. Jeden z ústředních objektů tranzitologického výzkumu, jímž je již od vzniku disciplíny fenomén státního převratu (coup d'état), tak zůstává mezi tuzemskými autory bez většího povšimnutí. Příčin může být vícero: nedostatečný zájem ze strany badatelů (oproti tématu pádu autoritativních a totalitárních režimů a jejich přerodu do demokracie, jež se u široké veřejnosti stala takřka synonymem dobrého vládnutí, zřetelně postrádá fenomén státního převratu jistou míru atraktivity), malá relevance studia státního převratu z pohledu české (československé) historické zkušenosti, ${ }^{3}$ nebo omezené kapacity relativně mladé české politologie. Avšak jedním z nejdůležitějších faktorů je koncepční nejednoznačnost, až zmatečnost kvantitativně i kvalitativně pokročilejš́ho výzkumu politologie anglosaského původu, která je pro českou politickou vědu hlavním inspirativním zdrojem.

Cílem této krátké studie, která je do značné míry inspirována metodologií zakotvené teorie (grounded theory), ${ }^{4}$ je prrispět k odborné diskuzi na poli výzkumu státního převratu a otevř́t prostor pro rozvoj formalizace a teoretické konceptualizace fenoménu, jehož závažnost se s novým stoletím nikterak nesnížila (především neblahý vývoj politického a bezpečnostního prostř́edí v regionu Blízkého východu a severní Afriky počínaje rokem 2011 tento trend potvrzuje). Předkládá sémantickou analýzu vybrané anglosaské odborné literatury (monografie, články, internetové zdroje), která je primárně či sekundárně (nejčastěji se jedná o výzkum ekonomických dopadů vojenské intervence do politiky) zaměřena na výzkum státního převratu $\mathrm{v}$ jeho rozličných podobách. V každém z těchto padesáti čtyř zdrojů je identifikováno několik klíčových termínů, z nichž vyplývá nejen definice převratu v takové podobě, v níž ji daný

\footnotetext{
2 Více o současných výzvách studií přechodů $\mathrm{k}$ demokracii a pro hlubší poznání problematiky viz Levitsky a Way (2006). O převažujících teoretických koncepcích v tranzitologii po skončení studené války viz Gans-Morse (2004).

3 Takový pohled na politickou evoluci českého národa je ovšem nesprávný. Ilustrativním pŕíkladem by mohlo být nahlédnutí do dobových odborných i laických pramenů a literatury období zrodu a konsolidace RČS (přibližně 1918-1930), v nichž se při soudobém i retrospektivním studiu událostí rozpadu Rakousko-Uherska téměř výhradně setkáme s výrazem „převrat““ jakožto označením pro vznik nového československého státu.

${ }^{4} \mathrm{~K}$ metodě zakotvené teorie viz např. Glaser, Barney a Strauss (1967); v české literatuře pak Braun (2008).
} 
autor užívá, nýbrž také širší sémantická vazba této definice na zvolený empirický rámec práce a původní badatelský záměr. Výsledkem je pak návrh terminologického řešení problému pro českou politologii, který pro ni představuje neucelené názvosloví anglosaské literatury. Účelem tohoto řešení, jehož dosažení vyžaduje vypořádat se shlavními terminologickými spory (vojenský vs. státní převrat, popř. vojenský vs. občanský převrat) mezi anglicky píśícími autory, není definitivní ukončení terminologické debaty, nýbrž usnadnění vstupu českých autorů do problematiky coup d'état.

První část př́íspěvku je věnována představení nejvíce se prosazujících terminologických tendencí anglosaské odborné literatury. Výstup je ve formě přehledové tabulky obsahující dílčí definice klíčových pojmů studií státního převratu, jejímž prínosem je ustanovení výchozího bodu pro hlubší terminologickou analýzu. V druhé části je poté provedena analýza tzv. prioritních výrazů neboli odborných termínů pro státní převraty, které převažují v terminologii jednotlivých autorů. $\mathrm{Na}$ základě srovnání jejich definitorních prvků jsou předloženy hlavní sporné body terminologie státních převratů a jejich vzájemné pozitivní i negativní vymezení.

Mezi rudimenty tranzitologické literatury, jež jsou rovněž zahrnuty do této sémantické analýzy, patři především díla generace badatelů šedesátých a sedmdesátých let 20. století: Samuel Finer (1962), William Thompson (1973), Gavin Kennedy (1974) nebo Morris Janowitz (1977) předkládají kvalitní a ucelené práce, jejichž obsah je však výlučně zaměřen na převraty, které jou dílem ozbrojených sil. Tato jednoznačná tendence je pouze reflexí dobového kontextu, kdy to byly téměř výhradně vojenští aktéři, kteří v zemích mimo spojenecké bloky bipolárního světa udávali tempo a směr politického vývoje. Výjimkou je Edward Luttwak (1969) a pozdější autoři, jako např́iklad Rosemary O'Kane (1987) a Marek Bankowicz (2012). Ti směřují svůj výzkum k širšímu pojetí státního převratu, čímž umožňují rozvoj nové, doposud převážně opomíjené epistemologie převratu iniciovaného civilními aktéry politického systému, která na přelomu století (vzhledem $\mathrm{k}$ vývoji $\mathrm{v}$ mezinárodní aréně) obhájila svou nadčasovost.

\section{Dosavadní terminologie: hlavní proud a vedlejší odchylky}

Při hledání teoretického základu pro výzkum státního převratu (StP) se pozorovateli nabízí co do šíre i hloubky velké množství méně či více kvalitních studií a článků. ${ }^{5}$ Jejich větší část tvoří prrípadové studie zaměřené na historicky ověřené prípady uskutečněných převratů, jež bývají odborné veřejnosti bud'

\footnotetext{
${ }^{5} \mathrm{~V}$ tomto případě mají čísla mnohem větší vypovídající hodnotu nežli slova: po zadání klíčového slova „coup“ do vyhledávání v databázovém systému EBSCO je nabídnuto 9519 odborných článků, JSTOR nabízí 2398, Project MUSE 1836 a ProQuest 530 (aktuální ke dni 23. 9. 2014; vyhledávání omezeno pouze na zdroje $z$ oboru politologie a oborů jí př́buzných).
} 
notoricky známé, nebo alespoň často mediálně referované. Takové předměty výzkumu totiž pro autora skýtají minimální úskalí a slouží zpravidla jako prostředek k empirickému ukotvení abstraktních teoretických modelů zasazených do jejich reálného rámce. Pro ucelený výzkum StP jako objektivně nahlíženého jevu, oproštěného od svazujícího časového a prostorového rámce, však tyto monotematické př́spěvky představují jistý metodologický problém: potenciál obecné aplikovatelnosti takto dosažených závěrů je bud’to značně omezován populací prrípadů sdílejících stejné či velmi podobné vstupní premisy, anebo v nich není obsažen vůbec. Epistemologicky totiž sledují cíl spočívající v dosažení hloubky poznání na úkor její šíře. Využitelnost těchto př́ípadových studií při aditivním výzkumu se tudíž skrývá v jejich partikulární empirické hodnotě coby „stř́pku v mozaice“.

$\mathrm{Na}$ pomyslném opačném pólu se pak nacházejí různé přehledové práce a teoretické koncepce, jejichž šíře výzkumného záběru umožňuje indukovat generalizující výroky, postavené na ověrujících a falzifikujících případech a odchylných výjimkách. Vysoká úroveň abstrakce, mnohdy uplatňovaná pro účely vybudování holisticko-ontologických teorií (velké teorie), ovšem může zaprríčinit ztrátu vazby teoretického modelu na skutečnost, z níž byl původně rozvijen. Stejnou logiku lze vysledovat i v př́padě používané terminologie. Nevyhnutelným důsledkem obrovského množství odborné literatury na téma státního převratu, jež je dnes českému badateli $\mathrm{k}$ dispozici, je rozvolňující se výrazový slovník, který dále způsobuje ztrátu „teoretické kompaktnosti“. Není to však problémem pouze dílčích politologických studií. Velká přehledová díla, jež v oboru společenských věd předkládají ucelený obraz o hlavních myšlenkových proudech a výzkumných směrech, se snadno (možná právě kvưli své všeobsažnému zaměřenî) dopouštění stejné chyby.

Britský filozof a politolog Andrew Heywood, jehož dílo mapující politické myšlenkové koncepce (Politické ideologie; česky poprvé 1994) je české politologické obci dobře známé, ve svém, dnes již zavedeném přehledovém díle Politologie (2002; česky poprvé 2004) předkládá, mimo jiné, ucelený pohled na události vedoucí ke změně režimu, při nichž právě armáda (military) sehrála klíčovou roli plánovače a realizátora. Výsledkem Heywoodovy analýzy odborné literatury, při níž se pokusil identifikovat styčné plochy $\mathrm{v}$ prŕstupech jednotlivých autorů a jejich děl a provést sjednocení (nikoli průnik) takto dosažených partikulárních závěrů, je jeho výrok o čtveřici „specifických okolnosti“ spjatých s již uskutečněnými vojenskými převraty: „ekonomická zaostalost, ztráta legitimity civilních vládců, konflikt mezi armádou a vládou, př́znivý mezinárodní kontext" (Heywood 2004: 407). Otázka prríčin převratu je obsahem druhé kapitoly této práce.

Z jím nabízeného prrístupu $\mathrm{k}$ nahlížení na teoretickou koncepci coup d'état vyplývá několik, pro účel naší studie symptomatických skutečností. Zaprvé, předmětem zájmu A. Heywooda není státní převrat $v$ obecné rovině, nýbrž poněkud vágně vysvětlený pojem „vojenský převrat“, resp. státní převrat, jehož 
strůjcem jsou ozbrojené síly státu stiženého převratem. Pokládá zde významové rovnítko mezi výrazy „coup d'état" na jedné straně a „vojenský puč“ na straně druhé (tamtéž: 406). Dopouští se ale jisté terminologické nejednoznačnosti tím, že v následující části svého textu definuje coup d’état jako „náhlé a násilné uchopení státní moci“, které „obvykle [sic!] uskutečňuje armáda“, a jako synonymum volí termín „puč“. Lze v zásadě souhlasit, že svržení vlády či režimu bývá obvykle provedeno za asistence, nebo zcela v režii ozbrojených sil, či jejich části. Vojenský převrat však ze své podstaty vždy vyžaduje rozhodné a aktivní zapojení vojáků do př́pravy a provedení konspirace. Tento jeho výrazový rozpor názorně dokládá panující zmatečný stav $\mathrm{v}$ terminologii zavedené na poli výzkumu problematiky státních př̀ratů.

\section{a. Souhrnná sémantická komparace: Powell a Thyne}

Terminologický problém nám může lépe dokreslit přehledová práce, jež by mapovala užívané názvosloví $\mathrm{v}$ konkrétních vědeckých textech a následně provedla jejich srovnání. Ve snaze odstranit ( $\mathrm{v}$ ideálním př́padě), či spíše minimalizovat negativní vliv „rozkošatěléc“ terminologie na badatelskou činnost, přistoupili Jonathan Powell, asistující profesor na University of Central Florida, a Clayton Thyne, pridružený profesor na University of Kentucky, k sestavení datové sady (dataset) a provedení právě takové komparativní studie. $Z$ pozice výzkumníků na poli vnitropolitické stability a vojensko-civilních vztahů doznali paradoxu, že ačkoli mohla každá př́padová studie státního převratu či srovnávací výzkum jejich sdílených rysů stavět na docela rozsáhlém odborně literárním fondu, bylo až zarážející, jak málo diskusního prostoru bylo věnováno otázce o podstatě převratu jako takového (Powell, Thyne 2011: 249).

Důsledkem absence plnohodnotné diskuze o definici fenoménu převratu bylo u mnohých autorů svévolné (nad)užívání pojmu a vznik řady jeho různých „pracovních“ významů. Powell a Thyne proto provedli analýzu čtrnácti odborných kvantitativních studií zabývajících se násilnými formami převzetí vlády a následně jejich vzájemné porovnání. Každá definice byla samostatně formalizována dle trojice hlavních atributů: cíle převratu, jeho pachatele a způsobu provedení. Na základě shody či rozdílu hodnot těchto atributů pak zamýšleli formulovat „konečnou definici“ převratu (tamtéž: 250). Tento jednoduchý, srozumitelný a logicky seřazený postup $\mathrm{k}$ dosažení konsenzuálního řešení terminologického problému sice dosáhl zajímavých zjištění (pro tabulkové znázornění viz níže), avšak obsahoval již od počátku zásadní chybu v př́istupu $\mathrm{k}$ porovnávanému fenoménu.

První z atributů, tedy účel, který má být převratem splněn, měl v Powellově a Thyneově analýze poměrně homogenní obsah. Analyzovaní autoři se pohybují $\mathrm{v}$ pomyslném rozmezí od svržení vrcholných představitelů exekutivy $(\mathrm{n}=3)$, přes vládu (5), mocenskou strukturu (3) až po celý politický režim (3). Výsledkem 
komparace třetího atributu, tedy způsobu uskutečnění převratu, bylo stanovení dvou elementárních premis každého převratu: musí být nutně ilegální a př́tomnost násilí není nutná, pokud existuje alespoň jeho hrozba. Druhý atribut byl, na rozdíl od obou zbylých, ve svém obsahu variabilnější, a zaslouží si o to větší pozornost.

Zdroje analyzované v textu Powella a Thynea lze podle tohoto parametru rozčlenit přibližně na čtyři skupiny: (A) první skupina označuje za iniciátory převratů výhradně ozbrojené síly (armed forces; regular armed troops; soldiers; military) daného státu; (B) druhá za ně považuje blíže nespecifikovanou koalici civilních a vojenských aktérů (civil or military; soldiers, politicians); (C) třetí zahrnuje do konspirátorů jiné ozbrojené složky státního či nestátního charakteru (security forces; police; mercenaries); a nakonec (D) čtvrtá skupina autorů pojímá parametr tvůrce převratu v širším, blíže nespecifikujícím pohledu (ruling or political elites; organized factions; segment of the state apparatus; groups, cliques, cabals, parties and factions). Tímto se opět dostáváme $\mathrm{k}$ již zmíněnému terminologickému problému. Jak je z výše uvedeného patrné, stav aplikovaného výrazového slovníku je spíše chaotický a pro tvorbu ucelené teorie státního převratu představuje komplikaci, která, pro potřeby rozvinutí debaty uvnitř české politologie, nutně vyžaduje řešení.

Význam terminologického problému, dále podloženého prací Powella a Thynea, je navíc zdůrazněn jejich vlastní špatnou formalizací ústředního studovaného jevu - prevratu. Oba badatelé totiž směšují dva pojmy, tedy vojenský převrat $(\mathrm{VoP})$ coby specifický způsob odstavení vládnoucích elit z rozhodovacích postů a státní převrat (StP) - svržení vlády chápané na obecné úrovni. Zařazením těchto dvou pojmů do jedné zkoumané množiny dále podporuje sémantický eklekticismus. Jedna část jimi citovaných autorů totiž prímo deklaruje svưj badatelský záměr věnovat se problematice VoP (Finer 1988; Kennedy 1974; McGowan 2007; Thompson 1973) a v tomto duchu rovněž definují předmět svého výzkumu. $V$ préevážné většině pak právě tito autoři spadají do první (A) ze čtyř výše uvedených skupin. Obdobná korelace, avšak v opačném smyslu, panuje rovněž u druhé části autorů, kteří se ve svých pracích zaměřují na studium StP, tedy převratu bez jakéhokoli adjektiva (nap̌r. Ferguson 1987; Luttwak 1979; O'Kane 1987). Tito pak tvoři zbylé tři skupiny (B, C, D).

Navzdory této chybě představuje práce Powella a Thynea prínos pro ucelenou terminologii převratů a náš výzkumný záměr. Zaprvé předkládají svou definici coup d'état ( $\mathrm{v}$ našem pojetí $\mathrm{StP}$ ), jež se opírá o srovnávací analýzu všeobecně uznávaných autorů literatury z oblasti studie převratů: „ilegální a veréjný pokus armády nebo jiných elit danébo státu o sesaz̧ení úradujicí výkonné moci" (Powell, Thyne 2011: 252). Zadruhé, tentokrát neúmyslně, poukazují na náznak jistých diferenčních linií nacházejících se mezi jednotlivými pohledy na fenomén převratu. Nyní se, převzavše cíl Powella a Thynea za svůj, pokusme provést obdobnou souhrnnou analýzu odborné literatury se zaměřením na vybrané výrazy ze slovníku tranzitologie, bez ohledu na zvolenou metodu (rozbor velkého, 
středního i malého počtu n-případi̊) a se snahou vyhnout se chybné formalizaci, jíž se oba autoři dopouštějí.

\section{b. Aditivní a rozšiřující sémantická analýza}

V rámci studie aplikované terminologie jsme provedli rozbor více než šedesáti odborných publikací a článků, přičemž padesát dva z nich, jež obsahovaly v různé míre rozpoznatelnou sémantiku hlavních zkoumaných veličin, bylo analyzováno z jejich perspektivy odborného slovníku teorie státního převratu ${ }^{6}$ (viz tabulka 1).

Účelem výběru literatury bylo provést rozbor u početného vzorku odborných zdrojů zahrnujícího jak základní literaturu, jež představuje rudimenty pro výzkum v oblasti StP (jedná se zejména o šest $z$ devíti monografii), ${ }^{7}$ tak články z odborných periodik (čtyřicet) a internetové zdroje (tři). Ačkoli to nebylo v původním zadání, podařilo se dosáhnout vyváženého poměru mezi studiemi na škále kvalitativní - kvantitativní výzkum (small-N: 16 ; medium-N: 17 ; large-N: 16). ${ }^{8}$ Navzdory tomu, že podstatou badatelského záměru všech vybraných zdrojů je studium převratů, v souhrnném celku předkládají autoři svým čtenářơm skutečně rozmanité množství formálně (od názvů ústřední proměnné - převratu) i obsahově (po definice převratu) odlišných terminologických pojmo̊.

Tabulka 1: Přehled vybraných zdrojů tematicky zaměřených na studium státních převratů.

\begin{tabular}{|c|c|c|c|c|c|c|}
\hline \multirow[b]{2}{*}{ zdroj } & \multicolumn{2}{|c|}{ parametry zdroje } & \multicolumn{4}{|c|}{ parametry coup d'état } \\
\hline & $n$ & $\begin{array}{c}\text { prioritní } \\
\text { výraz }\end{array}$ & objekt & subjekt & nástroj & cíl \\
\hline $\begin{array}{l}\text { Agyeman- } \\
\text { Duah } 1990\end{array}$ & 16 & $\begin{array}{l}\text { military } \\
\text { coup, } \\
\text { military } \\
\text { revolt }\end{array}$ & $\begin{array}{l}\text { vládnoucí } \\
\text { elita }\end{array}$ & $\begin{array}{l}\text { ozbrojené } \\
\text { síly }\end{array}$ & - & změna režimu \\
\hline $\begin{array}{c}\text { Babatope } \\
1981\end{array}$ & 19 & military coup & $\begin{array}{l}\text { nejvyšší } \\
\text { vládní } \\
\text { činitelé }\end{array}$ & $\begin{array}{c}\text { aktéři } \\
\text { vládnoucí } \\
\text { třídy }\end{array}$ & - & $\begin{array}{l}\text { personální } \\
\text { obměna } \\
\text { nejvyšších } \\
\text { úřadů }\end{array}$ \\
\hline $\begin{array}{l}\text { Banks } \\
2001^{*}\end{array}$ & 190 & $\operatorname{coup}$ & $\begin{array}{l}\text { vládnoucí } \\
\text { elita }\end{array}$ & - & vynucení & $\begin{array}{c}\text { násilná změna } \\
\text { vlády }\end{array}$ \\
\hline $\begin{array}{c}\text { Barraca } \\
2007\end{array}$ & 3 & military coup & civilní vláda & $\begin{array}{l}\text { ozbrojené } \\
\text { síly }\end{array}$ & - & vojenská vláda \\
\hline
\end{tabular}

${ }^{6} \mathrm{~V}$ politické vědě není pojem „teorie státního převratu“ zavedený. V rámci této studie s ním ovšem zacházíme z důvodu potřeby jej ustanovit.

7 Ferguson (1987); Finer (1962); Janowitz (1977); Kennedy (1974); Luttwak (1969) a O'Kane (1987).

${ }^{8}$ Tři metodologické skupiny byly ohraničeny v těchto intervalech: small- $N<5,5 \leq$ medium- $N \leq 50$, large- $N>50$. 


\begin{tabular}{|c|c|c|c|c|c|c|}
\hline $\begin{aligned} & \text { Belkin } \\
- & \text { Schofer } \\
& 2003\end{aligned}$ & 167 & coup & $\begin{array}{l}\text { politický } \\
\text { režim }\end{array}$ & $\begin{array}{l}\text { ozbrojené } \\
\text { síly }\end{array}$ & - & - \\
\hline $\begin{aligned} & \text { Belkin } \\
- & \text { Schofer } \\
& 2005\end{aligned}$ & 113 & military coup & $\begin{array}{l}\text { političtí } \\
\text { vůdci }\end{array}$ & $\begin{array}{l}\text { ozbrojené } \\
\text { síly }\end{array}$ & - & - \\
\hline $\begin{array}{c}\text { Ben-Eliezer } \\
1998\end{array}$ & 1 & military coup & - & armáda & - & vojenský režim \\
\hline $\begin{array}{c}\text { Bouzid } \\
2011\end{array}$ & 103 & coup d'état & $\begin{array}{l}\text { politický } \\
\text { režim, elity }\end{array}$ & $\begin{array}{l}\text { armáda, } \\
\text { úředníci, } \\
\text { politici, } \\
\text { monarcha }\end{array}$ & $\begin{array}{c}\text { fyzická } \\
\text { likvidace, } \\
\text { hrozba } \\
\text { vojenské } \\
\text { intervence }\end{array}$ & $\begin{array}{c}\text { náhlé } \\
\text { a nelegální } \\
\text { odstavení vlády }\end{array}$ \\
\hline $\begin{array}{c}\text { Cameron } \\
1998 \mathrm{a}\end{array}$ & 2 & autogolpe & $\begin{array}{c}\text { zákonodárný } \\
\text { sbor }\end{array}$ & exekutiva & $\begin{array}{c}\text { dočasné } \\
\text { zneplatnění } \\
\text { ústavy }\end{array}$ & $\begin{array}{c}\text { politický } \\
\text { systém } \\
\text { s rožšŕřenými } \\
\text { pravomocemi }\end{array}$ \\
\hline $\begin{array}{c}\text { Cameron } \\
1998 b\end{array}$ & 3 & $\begin{array}{l}\text { self-coup, } \\
\text { autogolpe }\end{array}$ & $\begin{array}{c}\text { zákonodárci, } \\
\text { soudy }\end{array}$ & prezident & $\begin{array}{l}\text { pozastavení } \\
\text { platnosti } \\
\text { ústavy }\end{array}$ & $\begin{array}{l}\text { širší exekutivní } \\
\text { pravomoci }\end{array}$ \\
\hline $\begin{array}{c}\text { Casper } \\
1991\end{array}$ & 1 & $\begin{array}{c}\text { military } \\
\text { intervention }\end{array}$ & civilní vláda & $\begin{array}{l}\text { armáda } \\
\text { společně } \\
\text { s civilisty }\end{array}$ & $\begin{array}{l}\text { vynucený } \\
\text { exil }\end{array}$ & $\begin{array}{l}\text { svržení vlády } \\
\text { nebo vojenský } \\
\text { režim }\end{array}$ \\
\hline Clark 2007 & 21 & $\begin{array}{l}\text { civilian- } \\
\text { organized } \\
\text { "revolution", } \\
\text { military coup }\end{array}$ & $\begin{array}{c}\text { vojenské } \\
\text { a civilní } \\
\text { vlády }\end{array}$ & - & - & - \\
\hline $\begin{array}{l}\text { Collihan - } \\
\text { Danopou- } \\
\text { los } 1993\end{array}$ & 1 & coup d'état & $\begin{array}{c}\text { klíčová část } \\
\text { státního } \\
\text { aparátu }\end{array}$ & $\begin{array}{c}\text { část } \\
\text { Ozbrojený } \\
\text { ch sil }\end{array}$ & infiltrace & $\begin{array}{c}\text { prrímá kontrola } \\
\text { nad politickou } \\
\text { mocí }\end{array}$ \\
\hline Costa 1993 & 1 & $\begin{array}{l}\text { autogolpe, } \\
\text { presidential } \\
\text { coup }\end{array}$ & $\begin{array}{l}\text { zákonodárná } \\
\text { moc, soudní } \\
\text { moc }\end{array}$ & $\begin{array}{l}\text { hlava } \\
\text { výkonné } \\
\text { moci }\end{array}$ & $\begin{array}{c}\text { pozastavení } \\
\text { platnosti } \\
\text { ústavy }\end{array}$ & $\begin{array}{c}\text { posílení } \\
\text { pravomocí }\end{array}$ \\
\hline Dix 1994 & 20 & $\begin{array}{l}\text { military } \\
\text { coup, } \\
\text { military } \\
\text { intervence }\end{array}$ & $\begin{array}{l}\text { politický } \\
\text { režim }\end{array}$ & armáda & - & vojenský režim \\
\hline $\begin{array}{l}\text { Ferguson } \\
1987^{*}\end{array}$ & 164 & coup d'état & vláda & $\begin{array}{l}\text { vojáci, } \\
\text { politici, } \\
\text { žoldáci }\end{array}$ & - & svržení vlády \\
\hline Finer $1962^{*}$ & & military coup & $\begin{array}{c}\text { civilní } \\
\text { autority }\end{array}$ & $\begin{array}{l}\text { Ozbrojené } \\
\text { síly }\end{array}$ & - & svržení vlády \\
\hline Fitch 2005 & 1 & $\begin{array}{c}\text { military coup } \\
\text { d'état }\end{array}$ & vláda & $\begin{array}{l}\text { ozbrojené } \\
\text { síly }\end{array}$ & $\begin{array}{l}\text { násilné } \\
\text { sesazení }\end{array}$ & - \\
\hline Fosu 2002 & 31 & coup d'état & elita & - & $\begin{array}{c}\text { násilné } \\
\text { odstranění }\end{array}$ & $\begin{array}{l}\text { nový politický } \\
\text { režim }\end{array}$ \\
\hline $\begin{array}{c}\text { Hanneman } \\
\text { - Steinback } \\
1990\end{array}$ & - & $\begin{array}{c}\text { military } \\
\text { coup, } \\
\text { military } \\
\text { intervention }\end{array}$ & exekutiva & armáda & - & $\begin{array}{c}\text { účast } \\
\text { vojenských elit } \\
\text { na vedení státu }\end{array}$ \\
\hline
\end{tabular}




\begin{tabular}{|c|c|c|c|c|c|c|}
\hline $\begin{array}{c}\text { Janowitz } \\
1977^{*}\end{array}$ & 151 & $\operatorname{coup}$ & $\begin{array}{l}\text { existující } \\
\text { režim }\end{array}$ & $\begin{array}{l}\text { organizo- } \\
\text { vaná } \\
\text { skupina }\end{array}$ & - & svržení režimu \\
\hline $\begin{array}{c}\text { Kebschull } \\
1994\end{array}$ & 38 & $\begin{array}{l}\text { coup d'état } \\
\text { (coup) }\end{array}$ & vláda & $\begin{array}{l}\text { civilní } \\
\text { skupiny, } \\
\text { ozbrojené } \\
\text { síly }\end{array}$ & $\begin{array}{c}\text { použití síly } \\
\text { nebo její } \\
\text { hrozba }\end{array}$ & $\begin{array}{c}\text { rychlé, } \\
\text { protiprávní } \\
\text { př́evzetí vlády }\end{array}$ \\
\hline$\underset{1974^{*}}{\text { Kennedy }}$ & 142 & military coup & - & $\begin{array}{l}\text { pravidelná } \\
\text { armáda }\end{array}$ & $\begin{array}{l}\text { využití nebo } \\
\text { hrozba } \\
\text { využití } \\
\text { ozbrojených } \\
\text { sil }\end{array}$ & $\begin{array}{c}\text { násilné převzetí } \\
\text { moci }\end{array}$ \\
\hline $\begin{array}{c}\text { Kposowa - } \\
\text { Jenkins } \\
1993\end{array}$ & 45 & $\begin{array}{c}\text { military } \\
\text { coup, } \\
\text { military } \\
\text { intervention }\end{array}$ & $\begin{array}{l}\text { ústřední } \\
\text { výkonná } \\
\text { moc státu }\end{array}$ & $\begin{array}{c}\text { pravidelné } \\
\text { ozbrojené } \\
\text { síly, } \\
\text { bezpeč- } \\
\text { nostní síly }\end{array}$ & $\begin{array}{c}\text { použití či } \\
\text { hrozba } \\
\text { použití síly }\end{array}$ & $\begin{array}{l}\text { nestandardní } \\
\text { uchvácení moci }\end{array}$ \\
\hline Lane 2008 & 11 & $\begin{array}{c}\text { revolutionary } \\
\text { coup }\end{array}$ & $\begin{array}{l}\text { politická } \\
\text { elita }\end{array}$ & $\begin{array}{l}\text { politická } \\
\text { opozice }\end{array}$ & $\begin{array}{l}\text { řízené } \\
\text { masové } \\
\text { protesty }\end{array}$ & $\begin{array}{c}\text { obnova } \\
\text { vládnoucí elity }\end{array}$ \\
\hline $\begin{array}{l}\text { Londregan } \\
\text { - Poole } \\
1990\end{array}$ & 121 & coup d'état & exekutiva & - & $\begin{array}{c}\text { použití či } \\
\text { hrozba } \\
\text { použití síly }\end{array}$ & $\begin{array}{c}\text { přenos } \\
\text { exekutivní } \\
\text { moci }\end{array}$ \\
\hline $\begin{array}{c}\text { Lunde } \\
1991\end{array}$ & - & $\begin{array}{c}\text { military } \\
\text { coup, civilian } \\
\text { coup }\end{array}$ & $\begin{array}{l}\text { civilní režim, } \\
\text { vojenský } \\
\text { režim }\end{array}$ & $\begin{array}{l}\text { armáda, } \\
\text { civilisti }\end{array}$ & 1 & - \\
\hline $\begin{array}{c}\text { Luttwak } \\
1969^{*}\end{array}$ & 132 & $\begin{array}{l}\text { coup d'état } \\
\text { (coup) }\end{array}$ & vláda & $\begin{array}{c}\text { část } \\
\text { státního } \\
\text { aparátu }\end{array}$ & konspirace & převzetí moci \\
\hline $\begin{array}{l}\text { Malul - } \\
\text { Shoham } \\
2006\end{array}$ & 59 & military coup & státní vláda & $\begin{array}{l}\text { pravidelné } \\
\text { ozbrojené } \\
\text { síly, } \\
\text { bezpeč- } \\
\text { nostní síly }\end{array}$ & $\begin{array}{c}\text { hrozba nebo } \\
\text { použití síly }\end{array}$ & $\begin{array}{c}\text { nestandardní } \\
\text { vládní přechod }\end{array}$ \\
\hline $\begin{array}{c}\text { Marshall } \\
\text { - Marshall } \\
2014^{\$}\end{array}$ & 75 & coup d'état & $\begin{array}{l}\text { autority } \\
\text { a úrady }\end{array}$ & $\begin{array}{l}\text { opoziční } \\
\text { nebo } \\
\text { politické } \\
\text { elity }\end{array}$ & násilná cesta & uchvácení moci \\
\hline $\begin{array}{c}\text { Mbaku } \\
1994\end{array}$ & 1 & military coup & $\begin{array}{l}\text { vrcholná } \\
\text { státní } \\
\text { exekutiva }\end{array}$ & $\begin{array}{l}\text { pravidelné } \\
\text { ozbrojené } \\
\text { síly, } \\
\text { bezpeč- } \\
\text { nostní síly }\end{array}$ & použití síly & $\begin{array}{c}\text { zmocnění se } \\
\text { státního } \\
\text { aparátu }\end{array}$ \\
\hline $\begin{array}{l}\text { McGowan } \\
2005\end{array}$ & 16 & $\begin{array}{l}\text { military-led } \\
\text { coup d'état }\end{array}$ & $\begin{array}{l}\text { političtí } \\
\text { vůdci }\end{array}$ & armáda & $\begin{array}{l}\text { násilné } \\
\text { přinucení }\end{array}$ & $\begin{array}{c}\text { svržení } \\
\text { politických elit }\end{array}$ \\
\hline $\begin{array}{l}\text { Moreno et } \\
\text { al. } 2004^{*}\end{array}$ & 19 & military coup & $\begin{array}{l}\text { národní } \\
\text { vláda }\end{array}$ & armáda & vojenská síla & svržení vlády \\
\hline $\begin{array}{c}\text { O'Kane } \\
1987^{*}\end{array}$ & 163 & coup & vláda & $\begin{array}{l}\text { civilisti } \\
\text { nebo } \\
\text { armáda }\end{array}$ & $\begin{array}{l}\text { hrozba nebo } \\
\text { použití násilí }\end{array}$ & svržení vlády \\
\hline $\begin{array}{c}\text { O’Kane } \\
1993\end{array}$ & 42 & $\begin{array}{l}\text { coup d'état } \\
\text { (coup) }\end{array}$ & $\begin{array}{l}\text { politická } \\
\text { elita }\end{array}$ & $\begin{array}{l}\text { skupina } \\
\text { konspirát } \\
\text { orů }\end{array}$ & - & sesazení vlády \\
\hline
\end{tabular}




\begin{tabular}{|c|c|c|c|c|c|c|}
\hline $\begin{array}{c}\text { Pion-Berlin } \\
- \\
\text { Trinkunas } \\
2009\end{array}$ & 3 & civilian coup & $\begin{array}{l}\text { občanský } \\
\text { sektor } \\
\text { společnosti }\end{array}$ & $\begin{array}{l}\text { zvolený } \\
\text { vůdce }\end{array}$ & masová akce & $\begin{array}{l}\text { odstavení } \\
\text { vládnoucí elity } \\
\text { od moci }\end{array}$ \\
\hline $\begin{array}{c}\text { Powell } \\
2014\end{array}$ & 47 & $\begin{array}{l}\text { democratic } \\
\text { coup, coup } \\
\text { d'état }\end{array}$ & $\begin{array}{l}\text { úřadující } \\
\text { exekutiva }\end{array}$ & $\begin{array}{l}\text { armáda, } \\
\text { státní elity }\end{array}$ & - & $\begin{array}{c}\text { změna } \\
\text { politického } \\
\text { režimu }\end{array}$ \\
\hline $\begin{array}{c}\text { Putnam } \\
1967\end{array}$ & 20 & $\begin{array}{c}\text { military } \\
\text { intervention }\end{array}$ & $\begin{array}{l}\text { civilní } \\
\text { politické } \\
\text { instituce }\end{array}$ & $\begin{array}{l}\text { ozbrojené } \\
\text { síly }\end{array}$ & - & vojenský režim \\
\hline $\begin{array}{l}\text { Quinlivan } \\
1999\end{array}$ & 3 & coup d'état & $\begin{array}{l}\text { klíčový } \\
\text { segment } \\
\text { státního } \\
\text { aparátu }\end{array}$ & $\begin{array}{c}\text { malá } \\
\text { skupina } \\
\text { pachatelů }\end{array}$ & infiltrace & $\begin{array}{c}\text { rychlé } \\
\text { uchvácení moci }\end{array}$ \\
\hline $\begin{array}{l}\text { Rittinger - } \\
\text { Cleary } 2013\end{array}$ & 17 & $\begin{array}{c}\text { military coup } \\
\text { d'état }\end{array}$ & $\begin{array}{l}\text { aktuální } \\
\text { držitel } \\
\text { výkonné } \\
\text { moci }\end{array}$ & $\begin{array}{l}\text { politická } \\
\text { elita } \\
\text { zahrnující } \\
\text { část } \\
\text { důstojník } \\
\text { ů }\end{array}$ & konspirace & převzetí moci \\
\hline $\begin{array}{l}\text { Siani- } \\
\text { Davies } \\
1996\end{array}$ & 1 & coup d'état & vláda & - & $\begin{array}{l}\text { minimální } \\
\text { krveprolití }\end{array}$ & převzetí moci \\
\hline $\begin{array}{c}\text { Tannahill } \\
1975\end{array}$ & 2 & $\begin{array}{c}\text { military } \\
\text { coup, } \\
\text { military } \\
\text { intervention }\end{array}$ & $\begin{array}{l}\text { civilní, } \\
\text { vojenská } \\
\text { nebo } \\
\text { armádou } \\
\text { řízená vláda }\end{array}$ & armáda & intervence & $\begin{array}{l}\text { civilní nebo } \\
\text { vojenská vláda }\end{array}$ \\
\hline $\begin{array}{c}\text { Thompson } \\
1973^{*}\end{array}$ & 135 & military coup & $\begin{array}{l}\text { vrcholná } \\
\text { exekutiva }\end{array}$ & $\begin{array}{l}\text { pravidelná } \\
\text { armáda }\end{array}$ & $\begin{array}{l}\text { použití nebo } \\
\text { hrozba násilí }\end{array}$ & - \\
\hline $\begin{array}{l}\text { Thompson } \\
1974,1975\end{array}$ & 49 & military coup & $\begin{array}{c}\text { vedoucí } \\
\text { exekutivní } \\
\text { orgány }\end{array}$ & $\begin{array}{l}\text { členové } \\
\text { pravidelné } \\
\text { armády }\end{array}$ & $\begin{array}{l}\text { použití síly či } \\
\text { hrozba jejího } \\
\text { použití }\end{array}$ & $\begin{array}{c}\text { svržení } \\
\text { představitelů } \\
\text { exekutivy }\end{array}$ \\
\hline $\begin{array}{c}\text { Thompson } \\
\quad- \\
\text { Christophe } \\
\text { rson } 1979\end{array}$ & 93 & military coup & $\begin{array}{l}\text { politický } \\
\text { režim; civilní } \\
\text { nebo } \\
\text { vojenské } \\
\text { vedení }\end{array}$ & armáda & útok & - \\
\hline $\begin{array}{c}\text { Trithart } \\
2013\end{array}$ & 2 & $\begin{array}{l}\text { democratic } \\
\text { coup, } \\
\text { autogolpe }\end{array}$ & $\begin{array}{l}\text { hlava státu, } \\
\text { zákonodárný } \\
\text { sbor, soudní } \\
\text { moc }\end{array}$ & $\begin{array}{l}\text { armáda, } \\
\text { opoziční } \\
\text { frakce } \\
\text { v armádě, } \\
\text { zákonodá } \\
\text { rná moc }\end{array}$ & $\begin{array}{l}\text { legislativní } \\
\text { výnos, } \\
\text { nucený exil }\end{array}$ & $\begin{array}{c}\text { odstoupení } \\
\text { hlavy státu, } \\
\text { posílení } \\
\text { exekutivy }\end{array}$ \\
\hline Varol 2012 & 3 & $\begin{array}{l}\text { democratic } \\
\text { coup d'état }\end{array}$ & státní špičky & $\begin{array}{l}\text { armáda, } \\
\text { nebo její } \\
\text { část }\end{array}$ & použití moci & nový režim \\
\hline Wells 1974 & 31 & $\begin{array}{l}\text { coup d'état, } \\
\text { military } \\
\text { intervention }\end{array}$ & státní správa & armáda & $\begin{array}{l}\text { agresivní } \\
\text { politická } \\
\text { akce }\end{array}$ & $\begin{array}{l}\text { rázné uchopení } \\
\text { moci }\end{array}$ \\
\hline
\end{tabular}




\begin{tabular}{|c|c|c|c|c|c|c|}
\hline $\begin{array}{l}\text { Wells, } \\
\text { Pollnac } \\
1988\end{array}$ & 21 & $\begin{array}{c}\text { military } \\
\text { coup, } \\
\text { military } \\
\text { intervention }\end{array}$ & - & $\begin{array}{l}\text { vojenská } \\
\text { klika }\end{array}$ & konspirace & ovládnutí státu \\
\hline $\begin{array}{l}\text { Whitehous } \\
\text { e } 2012\end{array}$ & 1 & $\begin{array}{c}\text { military } \\
\text { coup, putch }\end{array}$ & $\begin{array}{c}\text { nejvyšší } \\
\text { exekutivní } \\
\text { představitelé }\end{array}$ & $\begin{array}{c}\text { část } \\
\text { armády }\end{array}$ & $\begin{array}{c}\text { ozbrojený } \\
\text { střet }\end{array}$ & $\begin{array}{c}\text { odstavení } \\
\text { exekutivy od } \\
\text { moci }\end{array}$ \\
\hline $\begin{array}{c}\text { Zimmerma } \\
\text { nn } 1979\end{array}$ & 59 & $\begin{array}{c}\text { military coup } \\
\text { d'état }\end{array}$ & $\begin{array}{l}\text { správní } \\
\text { orgány, } \\
\text { vrchní } \\
\text { výkonné } \\
\text { orgány }\end{array}$ & $\begin{array}{l}\text { ozbrojené } \\
\text { síly, } \\
\text { pravidelná } \\
\text { armáda }\end{array}$ & $\begin{array}{l}\text { použití či } \\
\text { hrozba } \\
\text { použití síly }\end{array}$ & $\begin{array}{l}\text { politická } \\
\text { a/nebo } \\
\text { personální } \\
\text { změna }\end{array}$ \\
\hline
\end{tabular}

Zdroj: autor

* převzato z Powell, Thyne 2011: s. 250.

\$ Powell a Thyne citují verzi textu z roku 2007

U každého ze zdrojů jsme identifikovali parametr „prioritní výraz“ plynoucí z jejich specifického zaměření. Tímto prioritním výrazem se pro potřeby naší práce rozumí převažující terminologická forma ústředního zkoumaného jevu v intencích tranzitologie rozpoznatelného jako převrat. Daná forma převratu je identifikována jako převažující díky dvěma indikacím: prímým vyjádřením autora o svém záměru se takto označeným jevem zabývat (je uveden v samotném názvu zdroje), anebo častým výskytem v textu, přičemž primární výraz převyšuje výskyt ostatních forem použitých v daném zdroji. Díky rozpoznání prioritního výrazu je možné vysledovat či potvrdit neexistenci vzájemné souvislosti mezi formální podobou a sémantickým obsahem hlavního objektu badatelského záměru. Tím se vyhneme problému nesprávné formalizace, jež Powell a Thyne pravděpodobně přehlédli, a otevřeme si cestu k poznání různých abstrakcí státního převratu a zároveň jejich vzájemných horizontálních i vertikálních vazeb.

Všechny jednotlivé definice převratu byly v obecné rovině segmentovány do čtyř parametrů: vnitropolitický aktér nebo aktéŕi, proti nimž je převrat namíren (objekt); aktér nebo aktéŕi, kteří jsou strůjci převratu (subjekt); prostředky, jimiž je uskutečňování př̀vratu dosahováno (nástroj); a účel, jehož má být úspěšnou realizací převratu dosaženo (cíl). Naplněním těchto parametrů je formulována každá konkrétní ucelená definice převratu. Už na základě zjištění, že každá z definic je složeninou ze čtyř částí, je zř̌ejmé, že množství možných podob StP je početné.

V pojetí prvních dvou parametrů (objekt a subjekt) se vybrané zdroje dosti rozcházejí. Jak vyplyne z následujícího rozboru (viz tabulky 2 a 3), pro definici klíčových pojmů (prioritních výrazů) je zásadní rozpoznání především subjektu StP, udávající jednotlivým modelům převratu celkový rámec. Při použití stejného postupu, který byl zvolen při analýze textu Powella a Thynea, můžeme zdroje v zásadě rozdělit do čtyř, resp. dvou kategorií, z nichž většinu lze pro upřesnění rozčlenit do dalších podkategorií. 
Tabulka 2: Přehled kategorizace parametru „objekt“ definice převratu.

\begin{tabular}{|c|c|c|c|}
\hline & kategorie & subkategorie & př́íklady \\
\hline \multirow{6}{*}{ objekty } & \multicolumn{2}{|l|}{ Výkonné } & $\begin{array}{l}\text { nejvyšší vládní činitelé; civilní } \\
\text { vláda; vojenské a civilní vlády; } \\
\text { vláda; exekutiva; ústřední } \\
\text { výkonná moc státu; státní vláda; } \\
\text { vrcholná (státnî) exekutiva; } \\
\text { národní vláda; úřadující } \\
\text { exekutiva; aktuální držitel } \\
\text { výkonné moci; vedoucí } \\
\text { exekutivní orgány; civilní, } \\
\text { vojenská nebo armádou řízená } \\
\text { vláda; hlava státu; nejvyšší } \\
\text { exekutivní představitelé }\end{array}$ \\
\hline & \multicolumn{2}{|c|}{ režimní a celospolečenské } & $\begin{array}{l}\text { politický režim; existující režim; } \\
\text { civilní režim a vojenský režim; } \\
\text { občanský sektor společnosti }\end{array}$ \\
\hline & \multirow[b]{2}{*}{ obecné } & politické & $\begin{array}{l}\text { vládnoucí elita; političtí vůdci; } \\
\text { civilní autority; elita; politická } \\
\text { elita; civilní politické instituce }\end{array}$ \\
\hline & & $\begin{array}{l}\text { politické } \\
\text { a správní }\end{array}$ & $\begin{array}{l}\text { klíčová část (segment) státního } \\
\text { aparátu; autority a úřady; civilní } \\
\text { nebo vojenské vedení; státní } \\
\text { špičky; státní správa; správní } \\
\text { orgány }\end{array}$ \\
\hline & \multirow{2}{*}{ jiné } & zákonodárné & zákonodárný sbor \\
\hline & & $\begin{array}{l}\text { zákonodárné } \\
\text { a soudní }\end{array}$ & $\begin{array}{l}\text { zákonodárci a soudy; } \\
\text { zákonodárná moc a soudní moc }\end{array}$ \\
\hline
\end{tabular}

Zdroj: autor 
Tabulka 3: Přehled kategorizace parametru „subjekt“ definice převratu.

\begin{tabular}{|c|c|c|c|}
\hline & kategorie & subkategorie & příklady \\
\hline \multirow{4}{*}{ subjekty } & \multirow{3}{*}{ specifické } & vojenské & $\begin{array}{l}\text { ozbrojené síly; armáda; část } \\
\text { ozbrojených sil; vojáci; } \\
\text { pravidelná armáda; pravidelné } \\
\text { ozbrojené síly; členové } \\
\text { pravidelné armády; opoziční } \\
\text { frakce v armádě; armáda nebo } \\
\text { její část; vojenská klika }\end{array}$ \\
\hline & & kombinované & $\begin{array}{l}\text { armáda společně s civilisty; } \\
\text { civilisti nebo armáda; politická } \\
\text { elita zahrnující část důstojníků; }\end{array}$ \\
\hline & & civilní & $\begin{array}{l}\text { monarcha; exekutiva; prezident; } \\
\text { hlava výkonné moci; civilní } \\
\text { skupiny; opoziční nebo politické } \\
\text { elity; zvolený vůdce; } \\
\text { zákonodárná moc }\end{array}$ \\
\hline & Obecné & & $\begin{array}{l}\text { politici; politická opozice; } \\
\text { úředníci; bezpečnostní síly; část } \\
\text { státního aparátu; aktéŕi } \\
\text { vládnoucí tř́́dy; organizovaná } \\
\text { skupina; skupina konspirátorů; } \\
\text { státní elity; malá skupina } \\
\text { pachatelů }\end{array}$ \\
\hline
\end{tabular}

Zdroj: autor

V př́padě zbylých dvou parametrů (nástroj, cíl) dosáhli autoři analyzovaných textů, pokud ne shodných, pak velmi podobných závěrů. Z 35 zdrojů, v nichž byly prostředky použité pro uskutečnění StP explicitně uvedeny, celých $16 \mathrm{z}$ nich (46\%) označuje za převrat vnitropolitickou akci, prováděnou za použití násilí (síly) či pod jeho hrozbou. Dalších 7 zdrojů se tomuto vyjádření velmi bliží svým důrazem na agresivní, vnucující povahu nástrojů (vynucení, vynucený exil, použití moci, ozbrojený střet, útok atd.). Určitá forma násilí se tak objevuje u takřka 66 procent textů. A konečně za cíl převratu je převážnou většinou zdrojů (41 z 45) považováno, souhrnně řečeno, „uchvácení politické moci za účelem odstranění vlády nebo změny politického režimu“".

Primární výraz je, dle zjištěných poznatků, silně vázán na subjekt převratu. Výraz military coup (popr. military intervention, military coup d'état, military-led coup d'état) 
je ve výrazné většině středem badatelského záměru textů pracující se subjektem zapadajícím do subkategorie „vojenské“: celých 89 procent považuje za strůjce převratu ozbrojené síly (10), armádu (12) nebo jejich část (2). Pouze tři zdroje (11\%), zaměřující se na fenomén military coup, připouští existenci jiných než vojenských subjektů převratu: dva v subkategorii „kombinované“, jeden $\mathrm{v}$ „obecné“. Tato korelace mezi subkategorií vojenských subjektů a primárním výrazem military coup zřetelně naznačuje zaměření autorů velké části odborné literatury na jeden možný (z jejich pohledu možná jediný) model státního převratu, z něhož lze tím pádem vyvozovat jen závěry omezené jeho rámcem.

Výraz coup d'état (popř. coup) oproti předchozímu termínu absentuje zřetelnou vazbu na konkrétní subkategorii subjektu, jinými slovy subjekt coup d'état je variabilnější. Zdroje jsou $\mathrm{v}$ jeho př́padě rovnoměrně rozprostřeny nad všemi subkategoriemi: kombinované (6), obecné (5), vojenské (3) a civilní (1). Většina (73\%) označuje za subjekt bud'to vojenské a současně civilní aktéry, anebo jejich iniciátory nespecifikuje, čímž ponechává široký prostor pro zevšeobecnění. Rámec modelu státního převratu $\mathrm{v}$ tomto pojetí není koncepčně omezen, jako je tomu u předchozího př́padu.

Pokud provedeme rekapitulaci, vyplyne nám několik nepř́liš překvapivých, avšak nikoli nezajímavých zjištění o terminologii panující ve studiích o státních převratech. Zaprvé, mezi autory je rozšířena stále převažující, můžeme říci mainstreamová epistemologie StP. V jejím rámci je kladen důraz na roli ozbrojených sil, armády či bezpečnostních složek převratem postiženého státu a právě těmto aktérům je prripisována přímo exklusivní pozice při plánování a provedení převratu. Ten pak lze opatřit adjektivem plynoucím z podstaty jeho strůjců, čímž se dostáváme k ustálenému pojmu „,vojenský převrat“ (VoP). Vedle tohoto termínu se u mnoha zdrojů objevuje formálně i obsahově podobný výraz „vojenská intervence“ (VoI; viz níže).

Zadruhé, vedle převažujícího terminologického proudu jsme identifikovali významně zastoupenou tendenci chápat StP v širším politickém kontextu. Převrat je u těchto autorů pojímán coby důsledek konspirace aktérů, kterými sice může být a často bývá armáda nebo jiné ozbrojené složky státu, avšak o roli strůjce StP se dělí s civilními politickými subjekty, či jsou jimi zcela nahrazeny. Rozměr výzkumu se tímto rozšiřuje o nevojenskou sféru politiky a podtrhuje se důležitost terminologického vymezení „státního převratu“ od coup d'état militaire. A konečně zatřetí, někteř́ z autorů se pokouší ustanovit $\mathrm{v}$ odborné terminologii studií StP nové pojmy, které mají potenciál zlepšit identifikaci převratů na základě jejich specifických parametrů: „demokratický převrat“, „sebepřrevrat“ nebo „revoluční převrat". Mohou z terminologického hlediska znamenat nový přístup vymykající se dichotomii vojenský - civilní převrat a ustanovit se v primárním (převládajícím, vycházejícím ze subjektu coby definitorní veličiny) názvosloví StP. 


\section{c. Vojenský převrat nebo vojenská intervence?}

Převažující epistemologicky proud, který je charakteristický svým zaměřením na fenomén prrevratu v podobě zásahu ozbrojených sil do politického systému, není ani zdaleka jediný (jak vyplynulo z výše uvedeného srovnání). Navzdory jeho dlouhodobému rozvoji v politologickém diskurzu, trvajícímu v intenzivní podobě od poloviny minulého století, a značné oblibě ze strany anglosaských badatelů v oblasti problematiky StP, není zcela jednoznačně terminologicky ujednocen. Jednou z mála výrazových nejasností, které si zasluhují badatelskou pozornost, je koexistence pojmů „vojenský převrat" a „,vojenská intervence“.

Vojenský převrat $(\mathrm{VoP})$ - mainstreamovým proudem považovaný za jedinou formu státního převratu jako takového - se významově nezřídka překrývá s vojenskou intervencí (VoI). Problémem ovšem není jejich styčná plocha, nýbrž použití obou termínů $\mathrm{v}$ nestejných intencích. Zatímco $\mathrm{VoP}$ (v kategorizaci dle subjektu na ose specifické-vojenské; viz tabulka 3) je chápán jako okamžitá kinetická akce vyvolaná s cílem vyřešit ve prospěch jeho strůjců bezprostř̌ední degradaci politického, ekonomického, sociálního a/nebo bezpečnostního prostředí a stabilizovat vyhrocující se situaci (Ferguson 1987; Finer 1988; Luttwak 1979 a mnoho dalších), VoI je převážně dlouhodobým procesem, jehož účelem je formování a korigování politického režimu dle potřeb a zájmů ozbrojených sil (např. Casper 1991; Finer 1962; Hanneman, Steinback 1990; Putnam 1967; Rial 1989; Tannahill 1975). V diskuzi však vládne nejednotnost.

Část autorů pracuje s výrazem VoI jako v podstatě alternativním, možná více výstižným názvem pro jev, jež zbytek mainstreamového proudu pojmenovává vojenským př̀vratem: G. Casper kupř́kladu sjednocuje pod hlavičku VoI role ozbrojených sil jednak jako „měniče režimu“ (regime changer), ale také „,vládce režimu“ (regime ruler) (1991: 192). Obdobnou pozici zastává i J. Rial, který vojenskou intervencí v zásadě rozumí jakoukoli „akci [ozbrojených sil] coby politického aktéra“ (1989:103). Takové pojetí pak, i když necíleně, otevírá prostor k redukci významu VoI na obsah termínu VoP, který nadále zůstává př́kladem politické angažovanosti ozbrojených sil s největší mírou badatelského zájmu.

Vedle tohoto duplicitního pojetí vnímá řada autorů rozdílnost obou jevů a pokouší se determinovat jejich sémantický vztah: př́kladem mưže být dílo R. Putnama, jenž VoP a VoI rozumí jako dvěma projevi̊m stejného fenoménu, totiž militarismu (1967: 83, 89). S. Finer zase chápe VoI jako souhrnný výraz pro veškeré zasahování armády do politiky, čímž ji vưči VoP staví o úroveň výš, a rozpoznává její čtyři typy: „vliv“ (běžné, legitimní a legální vystupování ozbrojených sil v roli zájmové skupiny), „vydírání“ (konflikt mezi civilní a vojenskou sférou, stále v legálních mezích), „vytlačení“ (odstranění vlády násilnou či jinou cestou - VoP) a „doplnění“ (participace ozbrojených sil na utváření politického režimu - opět VoP) (1962: 127-148). 
Nejlépe se rozbor vztahu mezi VoP a VoI podařil R. N. Tannahillovi, americkému politologovi, který svou vědeckou činnost zaměřil na obecnou politickou vědu a její konceptualizaci. Ten, na základě rozboru dostupné odborné literatury, rozpoznal dva sémantické rámce, v nichž autoři s pojmem VoI zacházejí: (a) vojenská intervence jako událost, jinými slovy vojenský převrat. Tannahill k tomuto pojetí dodává, že se jedná o simplicitní koncepci, která je však pro analýzu zasahování armády do politického systému „nejméně použitelná“ (1975: 220-221). Druhé pojetí, tedy (b) vojenská intervence jako postup, je pro potřeby takové analýzy nejen vhodnější, ale rovněž převažující (tamtéž: 221-223). Své místo si pak v teoretickém př́stupu našla kvantifikace VoI vyjádřená délkou trvání vojenských režimů ve sledovaných státech (Dix 1994: 440-445).

Někteří autoři, jejichž badatelský zájem spadá čistě do této oblasti, zavádějí další specifické názvosloví, které má zamezit této významové rozdvojenosti a inovovat zavedený slovník: často se tak můžeme setkat s termínem „vojenská účast" (military involvement) (Hanneman, Steinback 1990: 2-3).

Právě z důvodu těchto snah o vzájemné sémantické odloučení obou termínů by neměl být českou politologií pojem „vojenská intervence“ zahrnut do terminologie teorie státního převratu a naopak být upřednostněna sémantika nyní již převažující v hlavním proudu odborné literatury.

\section{d. Občanský převrat: zpochyb̆̌ovaná existence}

Od hlavního epistemologického proudu, který byl předmětem předchozí části, se po celou dobu rozvoje výzkumu StP vydělovala značná část autorů, jež nechápala fenomén převratu pouze $\mathrm{v}$ intencích vojenského angažmá $\mathrm{v}$ politické sfére státu, nýbrž poukazovali na řadu převratů, $\mathrm{v}$ nichž ozbrojené síly daného státu bud'to nevystupovaly $\mathrm{v}$ roli primárního aktéra, anebo se zcela vzdaly možnosti svého aktivního zapojení do převratných událostí. Odlišnosti těchto dvou př́stupů monadického (zastoupeného výrazem military coup) a dyadického (coup d'état) dává vzniknout diametrálně rozdílné perspektivě $\mathrm{StP}$ a tím dále rozvádí konceptuální základy studia převratů do širší i hlubší komplexnosti.

Otázky, na nichž se ve svých odpovědích odborná literatura štěpí do dvou proudů, jsou tyto: (I) Je nějaký vnitropolitický aktér, vyjma ozbrojených sil, schopen provézt neústavní svržení vládnoucí elity? (II) Jestliže je vláda neústavně svržena vnitropolitickým aktérem, jedná se vždy o převrat? Autoři mainstreamového př́stupu převážně odpovídají v obou př́padech negativně a opírají své stanovisko o poznanou empirii (především četné VoP v Africe a Latinské Americe druhé poloviny minulého stoletî). Jejich empirismus je v konfliktu s idealistickým př́stupem druhého badatelského proudu. Avšak je nutné zdůraznit, že ani jeden z těchto proudů (empiristický a idealistický) není,

9 Tato pojmenování slouží pro účely naší práce a je vhodné vnímat je s jistou nadsázkou. Empiristický proud totiž při své teoretizaci používá normativní terminologii ustanovující sadu 
alespoň z terminologického hlediska, úplně jednotný. Každý z nich lze, s určitou mírou zjednodušení, rozdělit do dvou podpř́istupů (viz schéma 1).

Schéma 1: Epistemologické přístupy ve vztahu $\mathrm{k}$ terminologii studií převratů.

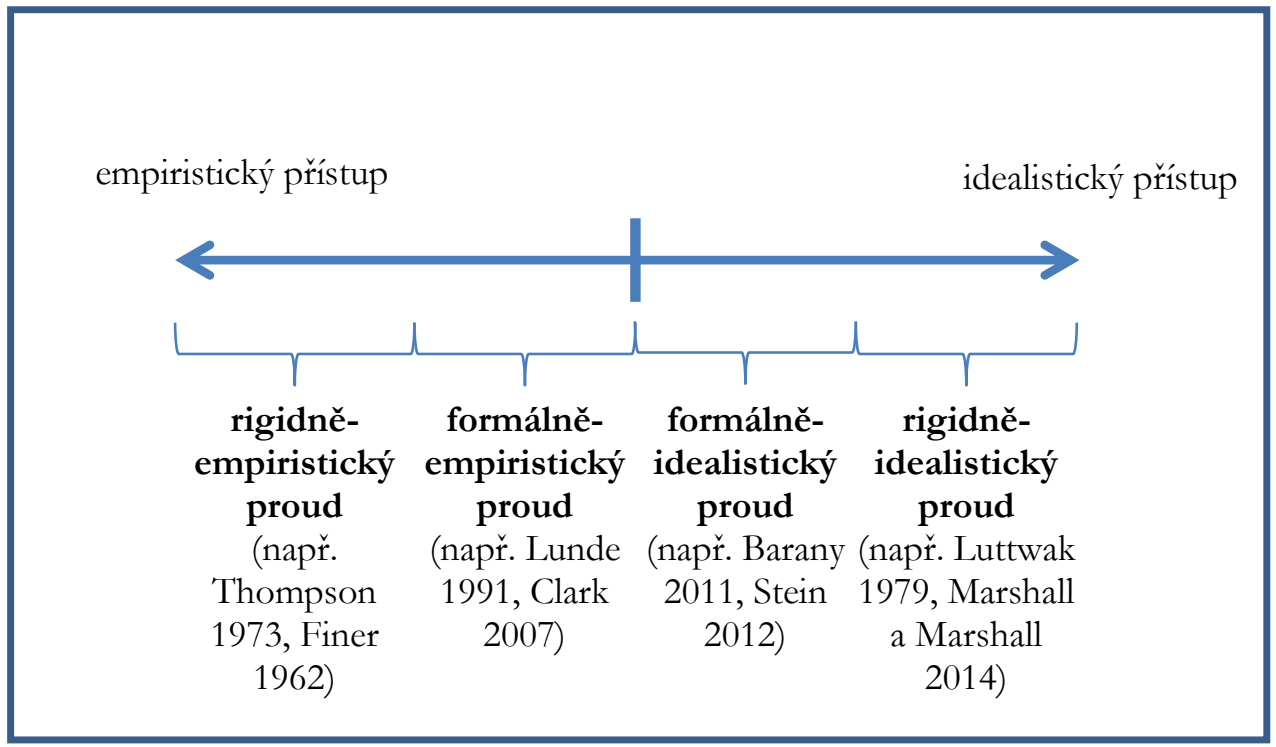

Zdroj: autor

Tabulka 4: Epistemologické př́stupy a jejich odpovědi na konfliktní otázky.

\begin{tabular}{l|c|c}
\hline \hline \multicolumn{1}{c|}{ epistemologické př́stupy } & odpověd' na I & odpověd' na II \\
\hline \hline rigidně-empiristický & ne & ne \\
formálně-empiristický & ne & ano \\
formálně-idealistický & ano & ne \\
rigidně-idealistický & ano & ano \\
\hline \hline
\end{tabular}

Všechny tyto dílčí př́stupy se mezi sebou diferencují v odpovědích na konfliktní otázky I a II (viz tabulka 4). Rigidně-empiristický př́stup se zaměřuje čistě na výzkum VoP, přičemž termíny „vojenský převrat“ a „státní převrat“ vnímá jako synonyma. Armáda je dle těchto autorů jediným relevantním

modelových typů státního převratu. Idealistický proud zase, na druhé straně, rovněž zakládá své terminologické závěry na zkušenostech vyplývajících z reálných historických převratů. Je ovšem možné pokládat za správný předpoklad, že epistemologie „empiristů“ směřuje od poznané skutečnosti k formulaci teoretických modelů, zatímco u „idealistů“ je tato orientace opačná. 
subjektem převratu. Druhý z př́stupů, formálně-empiristický, je ve svém náhledu na možnost ne-vojenského realizátora převratu umírněnější. Jejich výzkumy jsou cíleny na převraty provedené armádou, avšak na rozdíl od rigidně-empiristického se je snaží přesněji terminologicky vymezovat jako „vojenský převrat“. Tím ponechávají určitý konceptuální prostor pro modelování hypotetických podskupin převratů, jejichž tvůrci jsou bud’ koalice armády a civilních aktérů, anebo civilní aktérí s pasivní podporou armády. Nicméně StP (neboli $\mathrm{VoP}$ ) je u nich stále „zastřešujíci“ množinou převratů. Oproti tomu formálně-idealistický prrístup uznává možnost, že za svržením vládnoucí skupiny stojí jiný než vojenský aktér. Pro tyto prŕpady ovšem pracuje s širším názvoslovím a nezř́idka je označuje jinými termíny, než je převrat (např. revoluce, povstánî). A konečně poslední prrístup, rigidně-idealistický, pracuje s aplikovanou terminologií v užším rozsahu, než je tomu u předchozího př́stupu. Tito autoři proto, nejenže přiznávají existenci hypotetického modelu nevojenského, tedy občanského převratu, ale také ho rozvíjejí v model nadřazený všem ostatním druhům státního převratu.

Pro dosažení cílů naší práce se jeví jako nejvhodnější volba přijmout formálně-idealistický prŕstup $\mathrm{k}$ terminologickému ukotvení teorie StP za následováníhodný, čímž prriznáváme všeobecně existenci takového převratu, který je realizován bez zapojení ozbrojených sil. Pro takové rozhodnutí hrají zejména dva důvody. Zaprvé skýtá potenciál ustanovení nejpestřejšího terminologického slovníku, poněvadž není limitován jak př́sným induktivním vyvozováním z převažující historické empirie a zaměřením na převraty uskutečněné pouze armádou, tak názvoslovným eklektismem, v němž je jakékoli protiústavní svržení vlády považováno za některý typ státního převratu. Zadruhé nachází stále větší oporu v samotné empirii. Jestliže platí dlouho prijímaná hypotéza S. Huntingtona o prŕmém vztahu mezi existencí VoP a úrovní delegitimizace tradičních autorit ve společnostech, $\mathrm{v}$ nichž byly dosažením nezávislosti demontovány koloniální institucionální struktury (1968: 194), pak s postupným etablováním nových občansko-politických aktérů, jejichž rostoucí politický vliv nutně vytlačuje armádu z role jediné modernizační síly (Dix 1994: 445-446) a podílí se tak na procesu demilitarizace (Clark, 2007: 141), můžeme vysvětlit zvyšující se výskyt převratů řízených nevojenskými aktéry: Bangladéš 1990, Gruzie 2003, Ukrajina 2004, Bolívie 2005, Východní Timor 2006, Kyrgyzstán 2014, Ukrajina 2014, atd. (Lane 2008; Marshall, Marshall 2014). ${ }^{10}$

\footnotetext{
${ }^{10}$ Nabízí se otázka po kategorickém zařazení převratů provázejících rozpad komunistického bloku na konci osmdesátých a začátku devadesátých let 20. století. Ty lze rovněž označit za převraty vedené společenskými elitami bez zásadního přispění armády (pokud pomineme pokus o př̀evrat v Sovětském svazu roku 1991 a do určité míry také v Rumunsku). Jsou však důsledkem zcela jiného procesu, nežli emancipace nevojenské, občanské společnosti a etablování nových generací politiků nepocházejících z prostředí armády. Jedná se o výsledek eroze autoritářských/totalitních režimů, které ve své většině př́isně vymezily ozbrojeným silám prostor obrany proti vnější hrozbě, zatímco „vnitřního nepřítele“ potíraly tajné bezpečnostní služby zasahující do všech úrovní
} 
Aby mohl být konkrétní předmět badatelského zájmu označen za občanský převrat (civilian coup; ObP), je nutnou podmínkou neangažovanost ozbrojených sil (nikoli vojáků jako jednotlivců, ale vojenských útvarů jakožto celků) na straně iniciátorů (Pion-Berlin, Trinkunas 2009: 2). Odstavení vlád musí být plánováno a uskutečňováno opozicí legální či disentní, výhradně v podobě politické elity či za přispění masových protestů (viz také 1.1.6.). Dvojice amerických politologů David Pion-Berlin a Harold Trinkunas, odborníků v oblasti latinskoamerických studií, identifikují v těchto „občansko-občanských zápasech o moc“ poněkud překvapivě armádu za klíčového hráče (tamtéž: 3). Reakce armády a pozice, jíž bude během událostí hájit, je tudíž pro celkový průběh převratu a jeho výsledný konec rozhodující proměnou. ObP (v kategorizaci dle subjektu na ose specifické-civilní; viz tabulka 3) je proto v této logice zápasem mezi režimními a opozičními silami, během něhož si ozbrojené síly volí (často v rozporu s rozkazy politického vedenî) mezi třemi alternativními strategiemi jednání, tedy represí, rebelií a akomodací (tamtéž: 9-12), třetí z nich, jež se v důsledku rovná neutralitě.

\section{e. Úspěšný vs. neúspěšný převrat}

Jestliže už víme, s jak odlišnými pojetími tvůrců StP se vodborné literatuře pracuje, a víme, jak lze StP na základě této proměnné definovat, je potřeba se na státní př̀vrat podívat z jiného úhlu. Při posuzování zdánlivě nejdůležitějšího parametru, tedy výsledku pokusu o převrat, vyvstává ještě o něco variabilnější soubor možných odpovědí, než tomu bylo u otázky původu konspirátorů. Rozdílnost definicí úspěšného coup d'état je do značné míry výsledkem různých metodologických prŕstupů při výzkumu a jejich nároků na přesnost, či naopak použitelnost. Podle tohoto klíče je můžeme pro zjednodušení, avšak ne zcela významově přesně, rozčlenit do tř́ skupin: definice kvalitativní, kvantitativní a komparativní.

Kvalitativní výzkum, metodologicky zaměřen na analýzu případových studií s cílem co možná nejhlubšího poznání dané skutečnosti, nejčastěji zachází se zkoumaným objektem coby zcela specifickým jevem. Jako takový je popsatelný na základě zcela specifických událostí, průběhu, př́čcin a důsledků, kontextu i subjektivních cílů výzkumu. Badatelé v kvalitativním výzkumu (např. Trithart 2013; Fitch 2005) detailně studují pohnutky konspirátorů, jejich motivaci a konkrétní proměnné, jež v určité fázi vstupovaly do procesu prípravy a realizace převratu. Naplnění těchto zcela konkretizovaných požadavků, které mohou mít formu psychologické satisfakce, zlepšení postavení a materiálního bohatství (Clark 2007: 141), pak přirozeně, ve své většině, považují za indikátor úspěšnosti StP. Problémem tohoto př́stupu je jeho samotná podstata: zaměřením na detail

společenského života. Není proto překvapující, že tyto režimy, pro které je typický velmi nízký počet pokusů o vojenský převrat, byly ukončeny taktéž bez aktivního přispění armády. 
př́padové studie se značně zmenšuje potenciál zobecnitelnosti závěrů z něj plynoucích.

Jistým protiobrazem je kvantitativní přístup, jež pro hledání kauzálního efektu mezi sadou nezávislých proměnných a objektem výzkumu při velkém počtu př́padů vyžaduje značnou simplifikaci. Ta se nejběžněji projevuje v podobě zavedení různých indexů, jejichž hodnota se stanovuje na základě výpočtu či jednoduché rozhodovací logiky. Jejich autoři mnohdy vycházejí z povahy převratu coby akce vyžadující rychlé provedení (na rozdíl od revoluce). Osud konspirátorů je tudíz pevně spjatý s délkou doby, počínající zahájením jimi plánovaného StP. Úspěšnost převratu se pak posuzuje dle trvání prvotní, tedy exekutivní fáze, prričemž tato doba se u autorů různí: nejčastěji se pohybuje od čtyřiceti osmi hodin (např. Bouzid 2011; Wells 1974), přes jeden týden (napřr. Powell, Thyne 2011; Kebschull 1994; Thompson 1973), až po jeden měsíc (např. Marshall, Marshall 2014). Hlavní komplikací vyplývající z tohoto prrístupu je nejasnost vztahu mezi takto exaktně stanoveným kritériem a realitou jednotlivých studovaných převratů.

Díky střednímu počtu zkoumaných prvků má komparativní metoda širší pole náhledu na zkoumaný jev než kvalitativní a vyšší úroveň detailního poznání než kvantitativní metoda. Z tohoto důvodu jsou aplikované odborné termíny (mezi něž státní převrat patřì) definovány s jistým „puncem“ univerzálnosti a současně dojmem zakotvenosti v empirii. Autoři srovnávacích studií možná právě proto využívají svou partikulární definici StP jako východisko pro posuzování hodnot proměnných a úspěšnost/neúspěšnost převratu identifikují dle deklarovaných cílů, které jsou jedním z definitorních parametrů StP. Pokud je tedy převrat definován jako akce, jejímž účelem je svržení vlády (např. Ferguson 1987; Moreno et al. 2004; O’Kane 1987; Londregan, Poole 1990; Thompson 1974) nebo třeba ustanovení nového politického režimu (např. Dix 1994; Janowitz 1977; Powell 2014; Putnam 1967; Varol 2012), naplněním tohoto zamýšleného stavu je rozhodnuto o úspěchu. Slabinou př́stupu je ovšem jistá pravděpodobnost, že cíle daného převratu nebudou splněny beze zbytku. Na tento paradox upozorńuje E. Zimmermann, jenž tyto „kompromisní převraty“ (1979: 432) v zásadě rozděluje do dvou typů: zaprvé StP, v jehož rámci bylo dosaženo sesazení představitelů výkonné moci státu, avšak proti-př̀vratné síly jsou dostatečně silné, aby nadiktovaly podobu nové politické scény, jež může kolidovat s původními záměry konspirátorů; zadruhé situace, kdy nejsou tvůrci převratu ani obránci statu quo dostatečně silní $\mathrm{k}$ provedení rozhodujícího úderu vưči protistraně a více či méně př́żnivý výsledek se může dostavit až po delší době (tamtéž: 432-433). Ačkoli je občas ke stanovení úspěšnosti StP nutné operativní a subjektivní rozhodnutí badatele, zdá se tento prístup jako nejméně zatížený negativními důsledky jeho použití. 


\section{f. Demokratický převrat, revoluční prevrat a autogolpe}

Řada autorů se pokouší na poli tranzitologického výzkumu ustanovit výrazy, jež by nejlépe vystihovaly specifikum jimi zkoumaných jevů. Jedním z nich je americký ústavní právník tureckého původu Ozan Varol zaměřující se zejména na studium komparativních ústavních přechodů a vztahů mezi civilním a vojenským státním aparátem. Na základě výzkumu vojenského převratu v Turecku v květnu 1960 vypracovává Varol koncept tzv. „demokratického převratu“, přičemž právě události z jara 1960 využívá jako model par excellence.

Demokratický převrat (DeP) je typický, nikoli z důvodu zvláštních charakteristik jeho realizace či povahy jeho konspirátorů, ale pro aposteriorní poznání, které přináší. Varol jej definuje podle sedmi atributů: (1) převrat je namířen proti autoritářskému nebo totalitnímu režimu; (2) realizátoři převratu tím reagují na přetrvávající lidový odpor vůči režimu; (3) režim nehodlá lidovému odporu vůči své vládě odstoupit; (4) převrat je proveden armádou, požívající vysoké společenské prestiže; (5) cílem převratu je svržení režimu; (6) tvưrci převratu umožní konání svobodných voleb v brzké následující době; (7) výsledkem převratu je předání moci do rukou demokraticky zvolených elit (2012: 300). Vedle tohoto striktního slovního zavedení předkládá J. Powell ještě minimalizovanou definici, jež DeP vymezuje jako čin „svržení totalitárního či autoritářského režimu [...] za účelem jeho přechodu k demokracii““ (2014: 213214). Oproti autorovi koncepce DeP, jenž obecně označuje coup d'état za jednoznačnou „záležitost“ ozbrojených sil coby jeho výhradního iniciátora (Varol 2012: 297), pracuje Powell při svém hledání kauzálního vztahu mezi výskytem StP a četností přcechodů $\mathrm{k}$ demokracii s širším pojetím, navazujíce na svůj předchozí výzkum (viz Powell, Thyne 2011). ${ }^{11}$

Termín DeP si v odborné literatuře postupně nachází své místo. Jako jeden z príkladů lze uvést práci Alberta Tritharta používající model DeP pro popis převratů v Hondurasu (2009) a Nigeru (2010). Na rozdíl od Powella považuje Trithart, na jednu stranu, StP stále za reálnou hrozbu pro šíření demokracie ve světě. Avšak, na stranu druhou, nezpochybňuje koncepci DeP, nýbrž jej, s označením „správný převrat“ (s jistými normativními konotacemi) (Trithart 2013: 118), dále rozvádí. Za DeP již nepovažuje pouze takový převrat, který zprostředkovává přechod $\mathrm{k}$ demokratickému režimu, ale taktéž de facto „proti-

\footnotetext{
11 J. Powell dochází k zajímavému zjištění, že existuje kauzalita mezi převratem a demokratizací, čímž dodává zájmu o rozvíjení konceptu demokratického převratu smysl. Své závěry opírá o empirické důkazy dosažené kvantitativní metodou. Výsledkem je teze o „demokratizujícím“ vlivu př̀vratů, které, ačkoli rovněž vedly k nastolení dalšího autoritářského režimu, zejména po skončení studené války stále častěji zapříčiňují erozi a pád nedemokratických režimů (Powell 2014: 223). Státní převrat se tak stává nástrojem přechodu k demokracii.
} 
-převrat", jehož cílem je zabránit degradaci stávající demokracie způsobenou protiústavními snahami o zisk politické moci jinými státními aktéry. ${ }^{12}$

Jiným neotřelým a ambiciózním teoretickým modelem je tzv. revoluční převrat, který se znalcům názvosloví tranzitologie může zdát spíše jako oxymóron než smysluplné řešení terminologického sporu. Britský sociolog David Lane, specialista v oboru sociální transformace postkomunistických společností, se ve svém výzkumu setkal s již dlouho přetrvávajícím „hluchým místem“ v konceptualizaci teorií přechodů. Část převratných událostí, které se v obecném diskurzu označují jako tzv. barevné revoluce, ${ }^{13}$ totiž nedokázala soudobá tranzitologie přesvědčivě zařadit do existujících terminologických kategorií (navzdory snahám některých autorů, např. Siani-Davies 1996). Z tohoto důvodu předkládá $\mathrm{D}$. Lane model revolučního převratu (ReP), který vyplňuje prázdný prostor nacházející se mezi pojmy coup d'état a revoluce.

Terminologicky nesnadno zařaditelné svržení vlád a přechody mezi politickými režimy, mezi něž patří již zmíněné „barevné revoluce“, provokují některé autory ke snaze o nalezení odpovědi na otázku po jejich samotné podstatě. Většina z nich nachází odpověd’ bud'to $\mathrm{v}$ přirovnání $\mathrm{k}$ revoluci, príičemž se opírají zejména o typický průvodní jev - lidové demonstrace na podporu opozičních sil -, nebo k státnímu převratu, pro který zase hraje plánovitost protestů a mnohdy spolupráce př̀edstavitelů ancien regime a nastupující politické garnitury. Siani-Davies k těmto dvěma dichotomickým alternativám prridává ještě třetí pojem, tedy „lidovou vzpouru“ (popular uprising) jako synonymum „revolty“ nebo „rebelie“, avšak sám dochází k závěru o nevhodnosti jeho použití pro výstižnou kategorizaci „barevných revoluci““. Vzpoury jsou totiž pouhým dílčím projevem revoluce spočívajícím v participaci mas na odporu vůči odstraňované vládě a historické momenty, jež lze označit a jsou označovány jako lidové vzpoury, jsou de facto jen neúspěšnými revolucemi (Siani-Davies 1996: 460).

$\mathrm{Na}$ rozdíl od demokratického převratu spočívá hlavní definitorní rys ReP ve specifičnosti jeho průběhu, nikoli výsledného stavu jeho úspěšné realizace. „Barevné revoluce“ se vyznačovaly tím, že politická opozice byla v jejich průběhu

12 O normativním soudu „správnosti“ takto motivovaných převratů je ovšem možné vážně diskutovat. Jak poukazují mnozí autoři (např. Pion-Berlin, Trinkunas 2009: 27), každý StP má za následek oslabení tradičních i legálně zakotvených principů občansko-vojenských politických vztahů. Dochází tak k poškozování politické kultury země, v jejíž hranicích se uskutečňují.

13 Barevné revoluce je pojmenování zvláštního druhu pádů autokratických postkomunistických režimů, jež se udály převážně v druhé polovině devadesátých let minulého století (např. Bulharsko, Rumunsko, Slovensko) a první polovině první dekády století současného (nap̌r. Gruzie, Kyrgyzstán, Srbsko, Ukrajina). Zatímco však někteří autoři (nap̌r. Way 2008) označují za barevné revoluce přechody od nedemokratických (personalistických) režimů, jež vyrostly z mocenského vakua následujícího rozpad komunistického bloku, širší pojetí chápe barevnými revolucemi všechny lidově podnícené zhroucení autoritářských režimů nebo pokusy o ně v nejen postsovětském prostoru, ale také na blízkém východě (arabské jaro) a jihovýchodní Asii (Barma, Č́na, Filipíny). 
podporována právě masovými protesty proti stávajícím režimům (Way 2008: 56), což je naopak pro revoluci typické. Zde spočívá jejich hlavní sémantický problém. I přes tento rys nebyly „barevné revoluce“ spontánními důsledky živelného revolučního vývoje, nýbrž do značné míry opozičními elitami připravenými a koordinovanými akcemi (Lane 2008: 528-530), jež více či méně zdařile postupují dle apriorně sestaveného scénáře. Rozhodující role elit a absence průvodních znaků revolučního vývoje - exponované násilí prováděné na obou stranách konfliktu a konečná proměna politické, ekonomické a sociální struktury zasažené společnosti - proto potvrzují správnost zařazení „barevných revoluci“" do kategorie státních převratů. Právě pro demonstraci „lidového“ odporu vưči vládě a participaci širokých vrstev na veřejných protirežimních vystoupeních předkládá D. Lane jeho inovativní a přiléhavý terminus technicus.

Třetím a posledním zde probraným zvláštním pojmem studií převratů je tzv. sebepřevrat (autogolpe, self-coup, self-administered coup, někdy také presidential coup), který je sice mnohdy citován autory studií o státních převratech zejména Latinské Ameriky, na druhou stranu je jeho zařazení do terminologického slovníku teorie StP přinejmenším diskutabilní. Autogolpe vlastně nelze považovat ani za atypickou formu státního převratu, jedná se spíše o zvláštní druh protiprávní a násilné změny politického režimu, nesdílející s StP téměř žádný další definitorní parametr. ${ }^{14}$

Díky zcela specifickému zaměření a provedení autogolpe panuje většinou shoda mezi autory nad otázkou jeho definice. Slovy M. Camerona se v tomto př́padě jedná o uchvácení moci cestou „dočasného pozastavení platnosti ústavy a rozpuštění zákonodárného sboru ze strany výkonné moci“ (1998a: 220). Tento výrok můžeme považovat za minimální definici sebepřevratu, avšak k úplnosti je třeba upřesnění, že za pojmem „výkonná moc“ se nejčastěji skrývá nejvyšší představitel státu (prezident), a doplnění, poněvadž vedle vrcholného orgánu zákonodárné moci je pravidelně cílem represe rovněž moc soudní (Costa 1993), což si i M. Cameron posléze uvědomuje (1998b: 130-132). Stejně jako u coup d'état, také pro výsledek autogolpe představuje role, již se ozbrojené síly v průběhu politické krize zhostí, rozhodující faktor: zaujmou neutrální pozici, nebo, což je běžnější, postupují ve spolupráci se strůjci převratu.

Zde ale podobnost se státním převratem končí: subjektem StP jsou vnitrostátní aktéŕi nepodílející se přímo na výkonu předních orgánů politického rozhodovacího procesu, kdežto autogolpe je pripravován a realizován právě představiteli vrcholné exekutivy; objektem StP jsou nejvyšší patra výkonné moci

\footnotetext{
${ }^{14}$ Za sebepřevrat par excellence je v odborné literatuře považován politický vývoj v Peru roku 1992, během nichž se tehdejší peruánský prezident Alberto Fujimori rozpustil parlament, suspendoval ústavu a za asistence ozbrojených sil a cestou lidového plebiscitu upevnil prezidentskou pozici v rámci politického systému i svou personální moc. Je však pouze jedním z vícero príkladů: Francie 1958, Rusko 1991, Guatemala 1993 a další.
} 
politické a/nebo byrokratické sféry, zatímco zamýšlenými obět'mi násilné represe sebepřevratu jsou zbylé dvě složky státní moci.

Každý ze tří zde uvedených specifických abstrakcí - demokratický převrat, revoluční převrat a sebepřevrat - představuje výbornou teoretickou inovaci i metodologický vzor, protože pomáhají rozpoznat určité procesy proměny politické garnitury či režimu výstižnými a jednoduchými názvy a předkládají srozumitelný alternativní návod, jak postupovat při hodnocení konkrétních jevư teorií přechodů. Pro potřeby komplementace ujednoceného, použitelného a základního názvosloví studií o státních převratech ale nabízejí pouze velmi omezené uplatnění. Demokratickým převratem může být nazýván jen takový převrat, který naplnil definované parametry ve svém důsledku, avšak bez ohledu na charakter jeho tvůrců či aktérů, jež jsou jím postiženi. DeP se tudíž může stát jak vojenský, tak i občanský převrat, a zároveň jím nemusí být žádný z typů StP. Jedná se o sekundární typologii založenou na hodnocení dlouhodobého podmíněného vývoje. Podobný problém vykazuje i zasazení revolučního převratu do primární terminologie. ReP je rovněž pojmem vedlejší typologie, která je, jak jsme si ukázali výše, rozčleněna na linii rozsah zapojení/nezapojení mas do procesu odstraňování politických elit. Tento parametr může být naplněn napříč všemi typy StP a netvoří proto samostatný vzor. Konečně sebepřevrat splňuje podmínky pro zařazení do terminologie StP, poněvadž jeho svéráznost vychází z povahy subjektivních a objektivních aktérů, podle nichž jsou hodnoceny i ostatní druhy StP. Tvoří zcela jinou kategorii tranzitologických jevů, vůči níž se StP negativně vymezuje.

\section{Závěr}

Pokud zhodnotíme poznání, jehož jsme dosáhli analýzou vybrané odborné literatury, pak rozhodně nemůže být označeno za překvapující. Rozbor si kladl za cíl předložit čtenáŕi ucelenou terminologii studií státního převratu (StP), která je nezbytná pro rozvoj výzkumu v jakékoli společenskovědní disciplíně. Inovativní potenciál tohoto příspěvku se ovšem skrývá $\mathrm{v}$ dalších zjištěních, které analýza literatury cílená na slovní vymezení pojmů, jež by student teorií StP velmi obtížně (možná i neúspěšně) hledal i v rudimentárních pracích autorů (např. Finer 1962, Luttwak 1969), přinesla. Ty vyplynuly z postupného rozšiřování a prohlubování poznání problematiky StP během výzkumu (viz níže).

Definice StP je v odborné literatuře zpracována v množství přímo závratném, avšak tím i ve variabilitě stejně početné. Z provedeného srovnání lze, na základě převažujícího epistemologického př́ístupu autorů, StP vymezit následovně:

Státni prevrat je náblou protiustavni a protiprávni vnitropolitickou akci, jejimž zamýšleným cílem je odstranèni stávajicí vlády nebo żmèna politickébo rę̌imu za použití násilí, ci pod brozbou jebo urití. 
Termín „státní převrat“ (coup d'état) je zastřešující abstrakcí, kterou je možné dále kategorizovat dle několika proměnných. Nejběžnějším typologizačním znakem je povaha strůjce $\mathrm{StP}$, jež má vždy charakter společenské elity (na rozdíl od revoluce, u níž je podmínkou participace mas). Na této linii pak odborná literatura nejčastěji rozlišuje „vojenský převrat“ (military coup; VoP) od „občanského převratu“ (civilian coup; ObP):

Vojenský prevrat je specifickým státnim prevratem, jehož strujicem jsou ozbrojené sily prevratem stiženého státu. Ozbrojené sily mohou prì jeho realizaci yystupovat jako jeden aktér, nebo je iniciátorem prevratu jejich fragment, keterý tak operuje proti rozkazuim centrálníbo velení. Oz̧brojené síly realizuji prevrat zcela samostatnè, nebo za prižváni civilni politické elity, keterá v'̌ak vystupuje jako sekundárni aktér.

Občanský prevurat je specifickeym státnim prevratem, jehož strüjcem jsou společenské elity prevratem stiženébo státu nevojenskébo charakteru. Tyto pak jednaji bud'to za aktivníbo prispèni ozbrojených sil danébo státu, anebo bez vmésováni se ozbrojených sil do konfliktu mezi vládnimi a oporičnimi silami.

Tyto zde uvedené definice nejsou dílem jednoho či dvou autorů, ale spíše výsledkem přirozené evoluce teorií přechodů v oblasti studie státního převratu. První výzkumy, které můžeme datovat do šedesátých let 20. století, přistupovaly $\mathrm{k}$ tomuto vnitropolitickému jevu výhradně optikou (dis-)balance ve vojensko-civilních vztazích, tudíž coby produktu „patologického“ stavu, v němž se zejména státy Třetího světa mnohdy nacházely. Armáda byla v těchto dekolonizovaných společnostech poměrně nejlépe organizovaným politickým aktérem, jenž požíval velké nezávislosti na civilní vládě a sledoval své vlastní socioekonomické zájmy. K jejich naplnění se proto záhy po nabytí nezávislosti svých států uchýlily $\mathrm{k}$ využití svého mocenského potenciálu pro uskutečnění vojenských převratů, které změnily nejen dějiny a budoucnost rozvojových států, ale i celého mezinárodního politického systému. VoP se staly takřka normální cestou stř́dání národních vlád a proměn politických režimů především v Africe, jihovýchodní Asii, Latinské Americe i na Blízkém východě. Neexistoval rozumný důvod, proč by se právě vojenský převrat neměl stát v centru badatelského zájmu politické vědy.

Začátkem devadesátých let 20. století ovšem prrišla nejprve změna $\mathrm{v}$ usporáádání mezinárodní arény, poté $\mathrm{v}$ přístupu studentů StP k chápání fenoménu, jež začal postupně měnit svou podobu. Stejně jako západní a východní blok i země Třetího světa prošly transformací, kterou přinesla vlna globalizace v politické, ekonomické, sociální i bezpečnostní sféře. Společenský prostor těchto zemí počaly zaplňovat nové nestátní organizace, které vždy stojí u zrodu občanské společnosti. Politická emancipace doposud pasivního obyvatelstva v radě zemí vedla k odstranění armády z pozice jediné relevantní politické síly schopné vyvažovat a často i vyvracet moc centrálních vlád. Světem se prohnala vlna režimních přechodů, jejíž vliv na ustanovování nových demokracií popisuje S. Huntington (2008), a v důsledku níž se objevil nový jev, pro který se v odborné 
i laické veřejnosti ustálil název „barevné revoluce“. Bez ohledu na sémantickou správnost výrazu př́nesly tyto „revoluce“ významnou změnu na pole teoretické, protože se ve své většině jednalo o státní převraty do určité míry připravované, avšak rozhodně realizované opozičními politickými i celospolečenskými silami nevojenského charakteru. Jinými slovy, mnoho z nich bylo občanskými převraty. Do pozornosti badatelů se tak dostává typ StP, jehož existence je již lépe empiricky podložena a ověritelná.

Vedle těchto dvou tendenčních epistemologických proudů se však v odborné literatuře od počátku výzkumu profiluje generalizující, ve zpětném pohledu můžeme ř́ci nadčasový př́stup, popisující státní převrat bez adjektiv tak, aby byl výsledný abstraktní model reálného vnitropolitického jevu aplikovatelný na nejširší populaci studovaných př́padů. Tento coup d'état můžeme v pomyslné kategorizační hierarchii zařadit nad military coup a civil coup, které jsou tím pádem jeho prímými podkategoriemi. Z dosažených závěrů rozboru literatury tedy vyplývá, že $\mathrm{StP}=\{\mathrm{VoP}, \mathrm{ObP}\}$. Vedle této linie se formuje mnoho paralelních kategorií tranzitologických jevů, mezi něž patři zejména „revoluce“, „občanská válka“ (př́evzatá z teorií konfliktı̊) nebo „sebepřevrat“. Ten, ačkoli do značné míry podobný StP, představuje nezávislý proud výzkumu přechodů, poněvadž svou záměnou objektu (výkonná moc) za subjekt převratu se zcela vymyká definici StP. Platí tudíž vztah: sebepřevrat $\notin \mathrm{StP}$, ale sebepřevrat $\approx \mathrm{StP}$.

Dalšími dílčími poznatky, získanými díky této analýze a zmiňovanými výše, jsou zejména tyto: identifikace hlavního konceptuálního sporu mezi dominujícím a stále více se prosazujícím prístupem; návod k sestavení typologie státních převratů dle primární, ale částečně i sekundární linie. Pro začínající badatele studií státních převratů a možné tvůrce formalizované podoby teorie StP budou tyto dva vedlejší poznatky představovat překážku, jejíž překonání ovšem dále zvýší relevanci jimi dosažených závěrů. Při řešení první problému lze pouze doporučit zvolení prŕstupu, který $\mathrm{v}$ anglosaské politologické obci setrvale získává větší pozornost autorů. Tou je méně limitovaná perspektiva StP jakožto akce, jejímž strůjcem může být v současném globalizovaném světě jakýkoli politicky organizovaný aktér, nikoli pouze ozbrojená složka státu. Role armády však i nadále zůstává klíčová $\mathrm{v}$ tom smyslu, že plánování převratu musí zahrnovat hodnocení její možné reakce. Nemusí však být nutně strůjcem StP.

Druhá výzva, na druhé straně, spíše otevírá možnosti nového směřování výzkumu StP. Současný výzkum státních převratů se, z pohledu výrazové formalizace, více soustředí na rozpoznání a ukotvení modelů převratů nedefinovaných parametry subjekt (strůjce StP) a objekt (obět' StP), ale cíl a nástroj. Mezi takovými podobami StP jsme identifikovali „demokratický převrat", odvislý od cíle strůjců, a „revoluční převrat“, který je zase typický použitím specifických nástrojů použitých pro dosažení účelu StP. Taková perspektiva na výrazový slovník a typologii převratů otevírá značný prostor pro rozvoj teorií, které by mohly lépe reflektovat skutečnou podstatu jevů patrrících 
mezi události s nejvýznamnějším dopadem na politickou a bezpečnostní prostředí mezinárodního systému. Aby takové teorie posunuly úroveň poznání, další pozornost badatelů by měla být věnována zejména snaze o identifikaci klíčové veličiny: př́činné proměnné, nebo spíše souboru proměnných, jejichž naplnění či absence rozhodují o tom, zda lze uskutečnění převratu očekávat, či nikoliv.

\section{Bibliografie}

Ades, Alberto a Hak Chua (1997): „Thy Neighbor's Curse: Regional Instability and Economic Growth." Journal of Economic Growth 2(3): 279-304. DOI: 10.1023/A:1009782809329

Agyeman-Duah, Baffour (1990): „Military Coups, Regime Change, and Interstate Conflicts in West Africa." Armed Forces \&society 16(4): 547-570. DOI: 10.1177/0095327X9001600404

Antonius, George (1938): The Arab Awaking: The Story of the Arab National Movement. London: Hamish Hamilton.

Babatope, Ebenezer (1981): Coups: Africa and the Barrack Revolts. Enugu: Fourth Dimension Publishing.

Bankowicz, Marek (2012): Coup d'état. A Critical Theoretical Synthesis. Frankfurt am Main: Peter Lang.

Banks, Arthur (2001): Cross-National Time-Series Data Archive. Binghamton: Computer Systems Unlimited.

Barany, Zoltan (2011): „The Role of the Military.“ Journal of Democracy 22, no. 4, 24-35. DOI: $10.1353 /$ jod.2011.0069

Barany, Zoltan (2013): „Armies and Revolutions.“ Journal of Democracy 24(2): 62-76. DOI: 10.1353/jod.2013.0024

Barraca, Steven (2007): „Military Coups in the Post-cold War Era: Pakistan, Ecuador and Venezuela." Third World Quarterly 28(1): 137-154. DOI: 10.1080/01436590601081948

Belkin, Aaron a Evan Schofer (2003): „Toward a Structural Understanding of Coiup Risk." Journal of Conflict Resolution 47(5): 594-620. DOI: 10.1177/0022002703258197

Belkin, Aaron a Evan Schofer (2005): „Coup Risk, Counterbalancing, and International Conflict.“ Security Studies 14(1): 140-177. DOI: 10.1080/09636410591002527

Ben-Eliezer, Uri (1998): „Is a military coup possible in Israel? Israel and French-Algeria in comparative historici-sociological perspective." Theory and Society 27(3): 311-349. DOI: 10.1023/A:1006849601528

Bouzid, Bechir (2011): „Using a Semi-Parametric Analysis to Understand the Occurrence of Coups d'État in Developing Countries." International Journal of Peace Studies 16(2): 53 79.

Braun, Mats (2008): „Zakotvená teorie““ In: Petr Drulák (ed.), Jak ₹koumat politiku: kvalitativni metodologie v politologii a mezinárodních vǐtazích. Praha: Protál, 203-225

Cameron, Maxwell (1998a): „Latin American autogolpes: dangerous undertows in the third wave of democratisation." Third World Quarterly 19(2): 219-239. DOI: $10.1080 / 01436599814433$

Cameron, Maxwell (1998b): „Self-Coups: Peru, Guatemala, and Russia.“ Journal of Democracy 9(1): 125-139. DOI: 10.1353/jod.1998.0003 
Casper, Gretchen (1991): „Theories of Military Intervention in the Third World: Lessons from the Philippines." Armed Forces \& Society 17(2): 191-210. DOI: 10.1177/0095327X9101700202

Clark, John (2007): „The Decline of the African Military Coup.“ Journal of Democracy 18(3): 141-155. DOI: 10.1353/jod.2007.0044

Collihan, Kathleen a Constantine Danopoulos (1993): „Coup d'état Attempt in Trinidad: Its Causes and Failure." Armed Forces and Society 19(3): 435-450. DOI: 10.1177/0095327X9301900308

Costa, Eduardo (1993): „Peru’s Presidential Coup.“ Journal of Democracy 4(1): 28-40. DOI: 10.1353/jod.1993.0010

Dix, Robert (1994): „Military coups and military rule in Latin America.“ Armed Forces \& Society 20(3): 439-456. DOI: 10.1177/0095327X9402000307

Dvořáková, Vladimíra a Jiř́ Kunc (1994): O prechodech k demokracii. Praha: Sociologické nakladatelství.

Ferguson, Gregor (1987): Coup d'état: A Practical Manual. New York: Sterling.

Finer, Samuel (1962): The Man on Horseback: The Role of the Military in Politics. Boulder: Westview.

Fitch, J. Samuel (2005): „Post-Transition Coups: Ecuador 2000.“ Journal of Political and Military Sociology 33(1): 39-58.

Fosu, Augustin (2002): „Political Instability and Economic Growth: Implications of Coup Events in Sub-Saharan Africa." American Journal of Economics and Sociology 61(1): 329-348.

Gans-Morse, Jordan (2004): „Searching for Transitologists: Contemporary Theories of Post-Communist Transitions and the Myth of a Dominant Paradigm." Post-Soviet Affairs 20(4): 320-349.

Glaser, Barney a Anselm Strauss (1967): The Discovery of Grounded Theory. Strategies for Qualitative Research. Chicago: Aldline Transactions

Hanneman, Robert a Robin Steinback (1990): „Military Involvement and Political Instability: An Event History Analysis 1940-1980." Journal of Political and Military Sociology 18(1): 1-23.

Heywood, Andrew (2004): Politologie. Praha: Eurolex Bohemia.

Huntington, Samuel (1968): Political Order in Changing Societies. New Haven and London: Yale University Press.

Huntington, Samuel (2008): Tretí vlna: demokratizace na sklonku dvacátébo století. Brno: Centrum pro studium demokracie a kultury.

Janowitz, Morris (1977): Military Institutions and Coercion in the Developing Countries. Chicago: University of Chicago Press.

Kebschull, Harvey (1994): „Operation “Just Missed”: Lessons From Failed Coup Attempts." Armed Forces \&oSociety 20(4): 565-579. DOI: 10.1177/0095327X9402000405

Kennedy, Gavin (1974): The Military in the Third World. New York: Charles Scribner's Sons.

Kposowa, Augustine a Craig Jenkins (1993): „The Structural Sources of Military Coups in Postcolonial Africa, 1957-1984.“ American Journal of Sociology 99(1): 126-163. DOI: $10.1086 / 230231$

Lane, David (2008): „The Orange Revolution: ‘People's Revolution’ or Revolutionary Coup?" The British Journal of Politics and International Relations 10(4): 525-549. DOI: 10.1111/j.1467-856X.2008.00343.x 
Levitsky, Steven a Lucan Way (2006): „Linkage versus Leverage: Rethinking the International Dimension of Regime Change." Comparative Politics 38(4): 379-400. DOI: $10.2307 / 20434008$

Londregan, John a Keith Poole (1990): „Poverty, the Coup Trap, and the Seizure of Executive Power." World Politics 17(2): 151-183.

Lunde, Tormod (1991): „Modernization and Political Instability: Coup d'état in Africa, 1955-1985.“ Acta Sociologica 34(1): 13-32. DOI: 10.1177/000169939103400102

Luttwak, Edward (1969): Coup d'état. A practical handbook. Cambridge: Harvard University Press.

Malul, Miki a Amir Shoham (2006): „The Role of Culture and Economic Variables in Wars and Coups." Peace Economics, Peace Science and Public Policy 12(1): 1-9. DOI: 10.2202/1554-8597.1096

Marshall, Monty a Donna Marshall (2014): „Coup d'état Events, 1946-2013.“ Center for Systemic Peace, on-line (http://www.systemicpeace.org/inscr/CSPCoupsCodebook 2013.pdf) [ověřeno k 23. 9. 2014].

Mbaku, John (1994): „Military Coups as Rent-Seeking Behavior.“ Journal of Political and Military Sociology 22(3): 241-284.

McGowan, Patrick (2003):,African military coups d'état, 1956-2001: Frequency, trends and distribution." Journal of Modern African Studies 41(3): 339-370. DOI: 10.1017/S0022278X0300435X

McGowan, Patrick (2005): „Coups and Conflict in West Africa, 1955-2004.“ Armed Forces \&Society 32(1): 5-23. DOI: 10.1177/0095327X05277885

Moreno, Erika, Michael Lewis-Beck a Jacque Amoureux (2004): „Latin Rhythms: Coup Cycles in the America“. Working paper, on-line (http://citation.allacademic. com/meta/p_mla_apa_research_citation/0/8/3/6/8/pages83681/p83681-1.php)

O'Kane, Rosemary (1987): The Likelihood of Coups. Aldeshot: Avebury.

O'Kane, Rosemary (1993): „Coups d'État in Africa: A Political Economy Approach.“ Journal of Peace Research 30(3): 251-270. DOI: 10.1177/0022343393030003002

Pion-Berlin, David a Harold Trinkunas (2009): „Civilian Praetorianism and Military Shirking during Constitutional Crises in Latin America“. Working paper, RESDAL, online (http://www.resdal.org/experiencias/lasa2009-paperpion berlin-trinkunas.pdf) [ověřeno k 23. 9. 2014].

Powell, Jonathan (2014): „An assessment of the 'democrartic'coup theory." African Security Review 23(3): 213-224.

Powell, Jonathan a Clayton Thyne (2011): „Global instances of coups from 1950 to 2010: A new dataset." Journal of Peace Research 48(2): 249-259. DOI: $10.1177 / 0022343310397436$

Putnam, Robert (1967): „Toward Explaining Military Intervention in Latin America Politics.“ World Politics 20(1): 83-110. DOI: 10.2307/2009729

Quinlivan, James (1999): „Coup-proofing: Its Practice and Consequences in the Middle East.“ International Security 24(2): 131-165.

Rial, Juan (1989): „The Legitimacy of Military Intervention and the Option for Democracy in Latin America." In: Jürgen Kulhmann (ed.), Military Interventions and Democracy Security Policy and Defence in Finland. München: Sozialwissenschaftliches Institut der Bundeswehr, 67-120. 
Rittinger, Eric a Matthew Cleary (2013): „Confronting Coup Risk in the Latin American Left." Studies in Comparative International Development 48(4): 403-431. DOI: 10.1007/s12116-013-9128-9

Ríchová, Blanka (2000): Přebled moderních politologických teorií. Empiricko-analytický prìstup $v$ soudobé politické védè. Praha: Portál.

Sarkees, Meredith (2010): „The COW Typology of War: Defining and Categorizing Wars." Correlates of War, University of Michigan, on-line (http://cow.la.psu.edu /COW2\%20Data/WarData_NEW/COW\%20Website\%20-

$\% 20$ Typology $\% 20$ of $\% 20 w a r . p d f$ [ověřeno k 5. 9. 2014].

Sarkees, Meredith (2011):,Extra-state Wars: Definitions and Variables.“ Correlates of War, University of Michigan, on-line (http://cow.dss.ucdavis.edu/data-sets/COWwar/extra-state-wars-codebook) [ověřeno k 5. 9. 2014].

Siani-Davies, Peter (1996): „Romanian Revolution or Coup d'état?“ Communist and PostCommunist Studies 29(4): 453-465. DOI: 10.1016/S0967-067X(96)80026-2

Tannahill, R. Neal (1975): „Military Intervention in Search of a Dependent Variable.“ Journal of Political and Military Sociology 3(2): 219-228.

Thompson, William (1973): Grievances of Military Coup-Makers. Beverly Hills: Sage Publications.

Thompson, William (1975): „Regime Vulnerability and the Military Coup.“ Comparative Politics 7(4): 459-487. DOI: 10.2307/421422

Thompson, William a Jon Christopherson (1979): „A Multivariate Analysis of the Correlates of Regime Vulnerability and Proneness to the Military Coup." Journal of Political and Military Sociology 7(2): 283-289.

Thompson, William (1974): „Toward Explaining Arab Military Coups.“ Journal of Political and Military Sociology 2(2): 237-250.

Trithart, Albert (2013): „Democratic Coups? Regional Responses to the Constitutional Crises in Honduras and Niger." Journal of Public and International Affairs 24: 112-133.

Varol, Ozan (2012):,,The Democratic Coup d'état." Harvard International Law Journal 53(2): 292-356.

Way, Lucan (2008): „The Real Causes of the Color Revolutions.“ Journal of Democracy 19(3): 55-69. DOI: 10.1353/jod.0.0010

Wells, Alan (1974): „The Coup d'état in Theory and Practice: Independent Black Africa in the 1960s." The American Journal of Sociology 79(4): 871-887. DOI: 10.1086/225630

Wells, Alan a Richard Pollnac (1988): „The Coup d'état in Sub-Saharan Africa: Changing Patterns from 1956-1984." Journal of Political and Military Sociology 16(4): 43-56.

Whitehouse, Bruce (2012): „The Force of Action: Legitimizing the Coup in Bamako, Mali.“ Africa Spectrum 47(2-3): 93-110.

Zimmermann, Ekkart (1979): „Explaining Military Coups d'État: Towards the Development of a Complex Causal Model.“ Quality and Quantity 13(5): 431-441.

Ženíšek, Marek (2006): Prechody k demokracii v teorii a praxi. Plzeň: Vydavatelství a nakladatelství Aleš Čeněk. 


\title{
The Terminology of Coup d'état Studies: Its Use in Specialized Literature Between 1962 and 2014
}

\author{
SUMMARY
}

The discipline of political science known as transitology (or rather the theory of regime transition) is still not a consolidated discipline in the Czech political science milieu, even a quarter of a century since the fall of the communist regime. The attention of Czech authors is almost exclusively focused on research into the decay of political regimes and their transition to a democratic form of government. Meanwhile, the phenomenon of coup d'état, which has been a central subject of research interest in transitology since the establishment of the discipline, remains largely neglected by Czech authors. This has many reasons, but one of the most important factors is conceptual ambiguity (leading to confusion) in advanced quantitative and qualitative research into Anglo-Saxon scientific literature.

The aim of this short study, which is methodologically largely inspired by grounded theory, is to contribute to the scholarly discussion of problems in coup research and to open up a new space for the development and formalization of a theoretical conceptualization of the central research subject of transitology. To achieve this goal, it performs a semantic analysis of selected Anglo-Saxon political science literature (monographs, articles, Internet sources) which is primarily or secondarily focused on the phenomenon of coup d'état in its various forms. The study identifies several key terms in each of the 54 sources which reveal not only subjective definitions of the term coup in the ways the various authors use it, but also a broader semantic relationship between this definition on the one hand and selected empirical frameworks and initial exploratory work plans on the other. The result of this semantic analysis presents a proposal for resolving the issue of terminology for the needs of Czech political science, originally rooted in the fragmented terminology of Anglo-Saxon literature.

The main outcomes of the study, which result from identification of the prevailing epistemological approaches applied in coup d'état research, are generally applicable definitions: Coup d'etat is a sudden unconstitutional and unlawful internal political action whose intended goal is to remove the current government or to change the political regime with the use of violence or the threat of its use. The term "coup d'état" (coup) is a covering abstraction, which can be further categorized according to several variables. The most common distinctive variable is a coup plotter, which always has the character of some social elite (as opposed to revolution, which requires the participation of the masses). On this score, the literature frequently distinguishes between "military coup" and "civilian coup" (or rather civic coup): (1) A military coup is a specific type of coup in which the action is brought about by the armed forces of the state. The armed forces could act as a single actor, or the initiator of the coup could be a separated fragment of the armed forces, which operates against the orders of the central command. The armed forces carry out the coup all alone, or invite civilian political elites as secondary actors. (2) A civilian coup is a specific type of coup carried out by the non-military social elites of the state. These act either with the active participation of the armed forces of the state, or without their interference.

Contemporary research into coups is more focused on identifying and anchoring coup models which are defined not on the basis of subject (coup maker) or object (coup 
victim), but by the goals of coups and the instruments of their realization. This study identifies the "democratic coup" and "revolutionary coup" as such forms of coup, which are dependent on the plotters' aim (to establish a democratic regime) or, rather, specific tools used to achieve such an aim. Such a perspective on the vocabulary and typology of coup research opens up considerable scope for developing theories that could better reflect the true nature of a phenomenon that is among the most important in the sphere of international security. As such, the paper aspires to shape the future developments in the discipline of coup d'état studies not only within Czech political science. 